OPEN ACCESS

Edited by:

Wim Van den Ende,

KU Leuven, Belgium

Reviewed by:

Sergey Shabala,

University of Tasmania, Australia

Serge Delrot,

Université de Bordeaux, France

${ }^{*}$ Correspondence:

Suzy Y. Rogiers

suzy.rogiers@dpi.nsw.gov.au

Specialty section:

This article was submitted to

Plant Physiology,

a section of the journal

Frontiers in Plant Science

Received: 13 June 2017 Accepted: 05 September 2017 Published: 27 September 2017

Citation:

Rogiers SY, Coetzee ZA, Walker RR, Deloire A and Tyerman SD (2017) Potassium in the Grape Nitis vinifera

L.) Berry: Transport and Function.

Front. Plant Sci. 8:1629.

doi: 10.3389/fpls.2017.01629

\section{Potassium in the Grape (Vitis vinifera L.) Berry: Transport and Function}

\author{
Suzy Y. Rogiers ${ }^{1,2,3 *}$, Zelmari A. Coetzee ${ }^{2,3,4}$, Rob R. Walker ${ }^{3,4,5,6}$, Alain Deloire ${ }^{2,3,7}$ and \\ Stephen D. Tyerman ${ }^{3,6}$ \\ ${ }^{1}$ New South Wales Department of Primary Industries, Wagga Wagga, NSW, Australia, ${ }^{2}$ National Wine and Grape Industry \\ Centre, Charles Sturt University, Wagga Wagga, NSW, Australia, ${ }^{3}$ The Australian Research Council Training Centre for \\ Innovative Wine Production, University of Adelaide, Glen Osmond, SA, Australia, ${ }^{4}$ School of Agricultural and Wine Sciences, \\ Charles Sturt University, Wagga Wagga, NSW, Australia, ${ }^{5}$ Agriculture and Food (CSIRO), Glen Osmond, SA, Australia, \\ ${ }^{6}$ School of Agriculture, Food, and Wine, University of Adelaide, Urrbrae, SA, Australia, ${ }^{7}$ Department of Biology-Ecology, \\ SupAgro, Montpellier, France
}

$\mathrm{K}^{+}$is the most abundant cation in the grape berry. Here we focus on the most recent information in the long distance transport and partitioning of $\mathrm{K}^{+}$within the grapevine and postulate on the potential role of $\mathrm{K}^{+}$in berry sugar accumulation, berry water relations, cellular growth, disease resistance, abiotic stress tolerance and mitigating senescence. By integrating information from several different plant systems we have been able to generate new hypotheses on the integral functions of this predominant cation and to improve our understanding of how these functions contribute to grape berry growth and ripening. Valuable contributions to the study of $\mathrm{K}^{+}$in membrane stabilization, turgor maintenance and phloem transport have allowed us to propose a mechanistic model for the role of this cation in grape berry development.

Keywords: potassium, grapevine, Vitis vinifera, berry, fruit, ripening, phloem, xylem

\section{INTRODUCTION}

$\mathrm{K}^{+}$is a highly mobile macronutrient that is integral to a number of physiological and biochemical processes within plants. $\mathrm{K}^{+}$has a strong role in regulating the membrane potential of the cell and therefore is critical to the uptake of other ions and sugars. It is essential for plant signaling, osmoregulation, maintaining cation-anion balance, cytoplasmic $\mathrm{pH}$ regulation, enzyme activation and protein and starch synthesis (Wang and Wu, 2013; Ahmad and Maathuis, 2014; Shabala and Pottosin, 2014). It is also implicated in programed cell death and senescence (Shabala, 2009, 2017), which in the grape berry is variety dependent and linked to ripening disorders late in ripening (Tilbrook and Tyerman, 2008; Fuentes et al., 2010). At the plant level, this cation is involved in photosynthesis and numerous functions related to plant water relations including growth processes, turgor maintenance and phloem transport (Hsiao and Läuchli, 1986; Liesche, 2016). This macronutrient is important to the development of fruit such as the apple (Nava et al., 2008), tomato (Almeselmani et al., 2009), melon (Lester et al., 2010), peach (Song et al., 2015), pepper (Botella et al., 2017) and strawberry (Song et al., 2017) leading to increased fruit size, soluble solids and color. $\mathrm{K}^{+}$is the most abundant cation within the grape berry at all stages of its development (Hale, 1977; Hrazdina et al., 1984; Rogiers et al., 2006a; Martins et al., 2012). In concert with sugar accumulation, it accumulates rapidly during ripening. From an applied

Abbreviations: ABA, abscisic acid; ATPase, adenosine triphosphatase; $\mathrm{Ca}^{2+}$, calcium ion; $\mathrm{H}_{2} \mathrm{O}_{2}$, hydrogen peroxide; $\mathrm{HO}^{\bullet}$, hydroxyl radical; $\mathrm{K}^{+}$, potassium ion; ROS, reactive oxygen species; ${ }^{1} \mathrm{O}_{2}$, singlet oxygen; $\mathrm{O}_{2}{ }^{\bullet-}$, superoxide radical 
perspective, this cation has a strong influence on juice $\mathrm{pH}$ and therefore is also important for berry, juice and wine acidity and color (Mattick et al., 1972; Somers, 1977; Boulton, 1980; Walker and Blackmore, 2012). Moreover, high $\mathrm{K}^{+}$ can alter microbiological stability and fermentation processes (Walker et al., 1998). Given the importance of $\mathrm{K}^{+}$to plant functioning as well as grape and wine quality, the mechanisms driving the accumulation of this cation though the vine and into the berry compartments is worthy of further exploration.

The grape berry is a non-climacteric fruit and composed of the seeds surrounded by three tissue layers: the endocarp or the tissue surrounding the seed, the mesocarp, also referred to as the pulp or flesh, and the exocarp or skin (Harris et al., 1968; Pratt, 1971; Hardie et al., 1996). $\mathrm{K}^{+}$is present in all three berry compartments and our knowledge of its accumulation in relation to environmental and cultural factors such as nutrient addition, irrigation, canopy manipulation and rootstock selection has progressed considerably (see reviews by Mpelasoka et al., 2003; Kodur, 2011; Martins et al., 2012). Nonetheless, information on the role of $\mathrm{K}^{+}$in the grapevine and the berry specifically, is unclear. Moreover, the physiological, biochemical and molecular mechanisms responsible for $\mathrm{K}^{+}$accumulation into the berry have only recently received attention. By drawing together this and additional information from other plant systems, it is possible to generate novel hypotheses and compose a useful framework for a process-based model addressing the diverse physiological functions of this cation and its mode of transport into grape berries.

\section{THE LOCATION OF $\mathrm{K}^{+}$IN THE BERRY}

$\mathrm{K}^{+}$accounts for ca $80 \%$ of all the cations within a grape berry (Rogiers et al., 2006a). A grape berry can accumulate over $5 \mathrm{mg}$ of $\mathrm{K}^{+}$by harvest and the accrual into the seeds, mesocarp and exocarp is continuous from fruit set to maturity, but most rapid after the onset of ripening (Hale, 1977; Possner and Kliewer, 1985; Williams and Biscay, 1991; Rogiers et al., 2000, 2006b; Ramos and Romero, 2017). The mesocarp harbors the greatest proportion of $\mathrm{K}^{+}$within the berry. In Grenache Noir, this berry compartment accumulated $60 \%$ of the total berry $\mathrm{K}^{+}$, with $37 \%$ allocated to the exocarp and merely 3\% to the seeds (Etchebarne et al., 2009). Correspondingly, in Shiraz, 59\% and 32\% of the total berry $\mathrm{K}^{+}$ were attributed to the mesocarp and exocarp, respectively, with the seeds accounting for 6\% (Rogiers et al., 2006a). The brush (the vascular and associated parenchyma tissue proximal to the seeds) and the receptacle were also relatively minor sinks for $\mathrm{K}^{+}$ (Rogiers et al., 2006a).

On a fresh weight basis, the concentrations within the Shiraz exocarp were 2-fold greater than the mesocarp prior to veraison, but these differences were less obvious by harvest (Rogiers et al., 2006a). A different study on ripe Shiraz berries found skin concentrations six-fold greater than the flesh (Iland and Coombe, 1988). $\mathrm{K}^{+}$concentrations were also two- to seven- fold higher in Riesling, Cabernet Sauvignon and Chardonnay skins at harvest, relative to the mesocarp, for own-rooted vines as well as those grafted onto Ramsey (Walker et al., 1998; Gong et al., 2010). Knowledge on the concentrations within the exocarp are important for red winemaking since the skin is left in contact with the must for a period of time after crushing to enhance anthocyanin extractability. However, excessive extraction of $\mathrm{K}^{+}$may also occur (Walker et al., 1998) and this is thought to contribute negatively to wine quality as $\mathrm{K}^{+}$binds to tartaric acid increasing wine $\mathrm{pH}$ and decreasing the pigmented flavylium form of anthocyanins (Hale, 1977; Boulton, 1980; Walker and Blackmore, 2012). $\mathrm{K}^{+}$also contributes to decreasing free acid levels, altering the tartaric acid: malic acid ratio and forming insoluble $\mathrm{K}$ bitartrate crystals during fermentation and within the bottle during the aging process (Conde et al., 2007). Many soils of Australian grape growing regions are particularly high in K (Robinson, 1992; Mpelasoka et al., 2003) and this contributes to high pH juice (Rogiers et al., 2016), necessitating costly tartrate additions in the winery (Walker and Blackmore, 2012), especially in the warmer climates where excessive malate respiration is a concurrent issue.

\section{THE SUB-CELLULAR LOCATION OF $\mathrm{K}^{+}$}

$\mathrm{K}^{+}$is present in the cytosol most often at $100-200 \mathrm{mM}$ in soluble $\mathrm{K}^{+}$(ion) form (Shabala and Pottosin, 2010; Anschütz et al., 2014). During ripening, the vacuoles accumulate glucose and fructose at up to $1 \mathrm{M}$ (Conde et al., 2007), and this coincides with a doubling in vacuolar $\mathrm{K}^{+}$to $40-50 \mathrm{mM}$ (Keller and Shrestha, 2014). This is considerably less than the hypodermal cells of the berry exocarp harboring vacuoles with $\mathrm{K}^{+}$at up to 0.5-1 M (Storey, 1987). Considering that the hexose concentrations are substantial enough to result in the turgor mediated expansion required for growth, the physiological rationale for this increase in vacuolar $\mathrm{K}^{+}$may be related to its potential role in phloem transport. To prevent the cell from collapsing, cytosolic osmolarity is likely balanced by a combination of $\mathrm{K}^{+}$and other ions as well as organic osmolytes. Stable cytosolic $\mathrm{K}^{+}$concentrations are, however, critical for maintaining the activity of enzymes that require $\mathrm{K}^{+}$ as a cofactor, such as pyruvate kinase (Armengaud et al., 2009). Apoplastic solutes are significant in grape berries (Wada et al., 2008) relative to other fruit. But there are cultivar differences in apoplastic $\mathrm{K}^{+}$concentrations of the mesocarp (Keller and Shrestha, 2014), possibly a function of ripening related loss in cell vitality and increased membrane leakiness (Tilbrook and Tyerman, 2008) as indicated by reduced electrical impedance within the apoplast (Caravia et al., 2015). Environmental influences such as light intensity can also modulate apoplasmic $\mathrm{K}^{+}$concentration (Shabala and Wilson, 2001). The complexity of determining apoplastic and vacuolar $\mathrm{K}^{+}$concentrations is aggravated by the presence of gradients in apoplastic and vacuolar $\mathrm{K}^{+}$concentrations across the berry, and this is driven by the diverse metabolic storage functions of cells according to their location (e.g., anthocyanin containing vacuoles in the exocarp). 


\section{LONG DISTANCE TRANSPORT OF $\mathrm{K}^{+}$}

\section{$\mathrm{K}^{+}$Uptake and Partitioning}

The fruit harbor most of the $\mathrm{K}^{+}$within the grapevine (Pradubsuk and Davenport, 2010; Degaris et al., 2016). $\mathrm{K}^{+}$accumulation into the berry is a function of availability and uptake by roots from the soil (Ruhl, 1989; Wang et al., 2010), the extent of $\mathrm{K}^{+}$redistribution from leaves (Coombe, 1992) and mobilization from storage sinks within the woody structures of the vine (Conradie, 1981; Williams and Biscay, 1991). Alkaline soils $(\mathrm{pH}>7.0)$ are associated with reduced $\mathrm{K}^{+}$availability due to potentially increased $\mathrm{Ca}^{2+}$ and $\mathrm{Mg}^{2+}$ uptake, to the point that $\mathrm{K}^{+}$deficiency can occur (Hannan, 2011). $\mathrm{K}^{+}$uptake is stimulated by warm spring soil temperatures as a result of increased diffusion rates and root activity (Clarke et al., 2015). A rootstock study indicated that uptake of $\mathrm{K}^{+}$was dependent on root traits such as total root length, total root surface area and percentage of small diameter roots $(<0.5 \mathrm{~mm})$ (Kodur et al., 2010). Rootstock differences were also apparent in the proportion of $\mathrm{K}^{+}$that was retained in the root systems or moved upward to the shoots in grafted and ungrafted vines, despite similar uptake and transpiration rates (Kodur et al., 2010, 2011).

Soil solutions contain $\mathrm{K}^{+}$concentrations several orders of magnitude lower than the plant (Ma et al., 2012) and thus considerable energy is invested in its uptake. $\mathrm{K}^{+}$is taken up across the plasma membrane of root cells by membrane transporter and channel proteins that can display high and low affinity uptake kinetics (Chérel et al., 2014). Cuéllar et al. (2010) has demonstrated that a low affinity Shaker $\mathrm{K}^{+}$channel VvK1.1 is mainly expressed in the cortex of grapevine roots and appears to be involved in $\mathrm{K}^{+}$uptake from external media. It is likely that more $\mathrm{K}^{+}$transporters will be characterized in roots of the grapevine, similar to other plants.

It is unclear when and by how much $\mathrm{K}^{+}$is remobilized to the fruit from the reserve pools in the woody structures or from temporary storage in the vegetative shoots and leaves. Reserve mobilization from woody stores was estimated to provide less than $10 \%$ of the annual nutrient requirements of the vine (Conradie, 1981). From bud burst to bloom, remobilisation from the perennial components contributed to most of the $\mathrm{K}^{+}$within the growing shoots and inflorescences (Pradubsuk and Davenport, 2010), presumably due to the lack of new fine root growth and slow root uptake in the cool soils (Clarke et al., 2015). Subsequently, uptake from the soil occurred from bloom to harvest, but decelerated after veraison (Pradubsuk and Davenport, 2010). The replenishment of the perennial $\mathrm{K}^{+}$ storage pools occurs at various periods across the growing season and may also compete with berry development (Pradubsuk and Davenport, 2010). Post veraison, $\mathrm{K}^{+}$was remobilized from the leaves and shoot tips back to the woody tissues (Pradubsuk and Davenport, 2010) and was also reported to support fruit development in Chenin Blanc (Conradie, 1981) and Cabernet Sauvignon (Williams and Biscay, 1991), but this was not evident in Pinot Noir (Schreiner et al., 2006). To elucidate $\mathrm{K}^{+}$transport mechanisms, ${ }^{86}$ rubidium $\left({ }^{86} \mathrm{Rb}^{+}\right)$was employed as a substitute for $\mathrm{K}^{+}$because of its similar absorption and distribution characteristics (Läuchli and Epstein, 1970). Upon foliar application, ${ }^{86} \mathrm{Rb}^{+}$was transported mainly to the berries at all stages of development, but with greatest intensity after veraison (Zhenming et al., 2008). The extent of $\mathrm{K}^{+}$relocation from the leaves to the fruit is thus likely dependent on the availability and uptake from the soil, mobilization from leaves and the status of $\mathrm{K}^{+}$reserves in the plant. However, plant water status and rates of phloem flow (Epron et al., 2016) are also important to $\mathrm{K}^{+}$relocation, as are leaf microclimate through its influence on the extent of photosynthesis and phloem loading at the source (Liesche, 2016). Finally, sink activity and demand also drive phloem transport processes (Marcelis, 1996) and thus $\mathrm{K}^{+}$ relocation.

\section{Phloem and Xylem Mobility}

$\mathrm{K}^{+}$is classified as an element with high mobility in the phloem (Marschner, 1995). This element is also transported through the xylem but at one 10th the concentrations of the phloem (Keller, 2015). After root uptake and transport through the xylem to the shoots, berry pedicel girdling studies confirmed that the phloem is the predominant route for $\mathrm{K}^{+}$ entry into the berry after veraison (Rogiers et al., 2006b). Prior to veraison the daily accumulation rate of $\mathrm{K}^{+}$into Shiraz berries is relatively slow at approximately $20-40 \mu \mathrm{g}$ per day and then increases 2-4 fold until berries attain maximum weight at which point $\mathrm{K}^{+}$accumulation slows and eventually ceases (Rogiers et al., 2000, 2006a,b) (Figure 1). Likewise, in Pinot Noir (Creasy et al., 1993) and Cabernet Sauvignon (Ollat and Gaudillère, 1996), $\mathrm{K}^{+}$accumulation into berries accelerated after veraison. This pattern of initial slow $\mathrm{K}^{+}$entry prior to veraison accords with the estimation by Greenspan et al. (1996) that phloem water contributes to less than $10 \%$ of total inflow prior to veraison. With the onset of ripening, however, the authors estimated a 10 -fold increase in the rate of phloem flow.

Drivers for the increased phloem contribution and $\mathrm{K}^{+}$ accumulation upon ripening include (1) the switch from symplastic to apoplastic phloem unloading (discussed below) and (2) the decline in xylem flow. At veraison, the contribution of the xylem to berry growth appears to decline (Düring et al., 1987; Findlay et al., 1987). The precise reasons for the decline in xylem flow after veraison remain unclear but may be related to a weakening in a hydrostatic gradient within the berry apoplast (Bondada et al., 2005; Scharwies and Tyerman, 2016) possibly due to low transpiration (Greer and Rogiers, 2009) as a result of decreasing surface conductance and the occlusion of the stomata with waxes (Blanke and Leyhe, 1987; Mullins et al., 1992; Rogiers et al., 2004). All things considered, variety differences and environmental factors such as irrigation and the daily variation in the evaporative gradient between the berry and the atmosphere may explain the inconsistent xylem flow patterns. Changes in berry transpiration as well as the reduced xylem contribution to the water and nutrient economy of the berry undoubtedly have large consequences on phloem transport and unloading mechanisms and thus $\mathrm{K}^{+}$accumulation into the berry. 


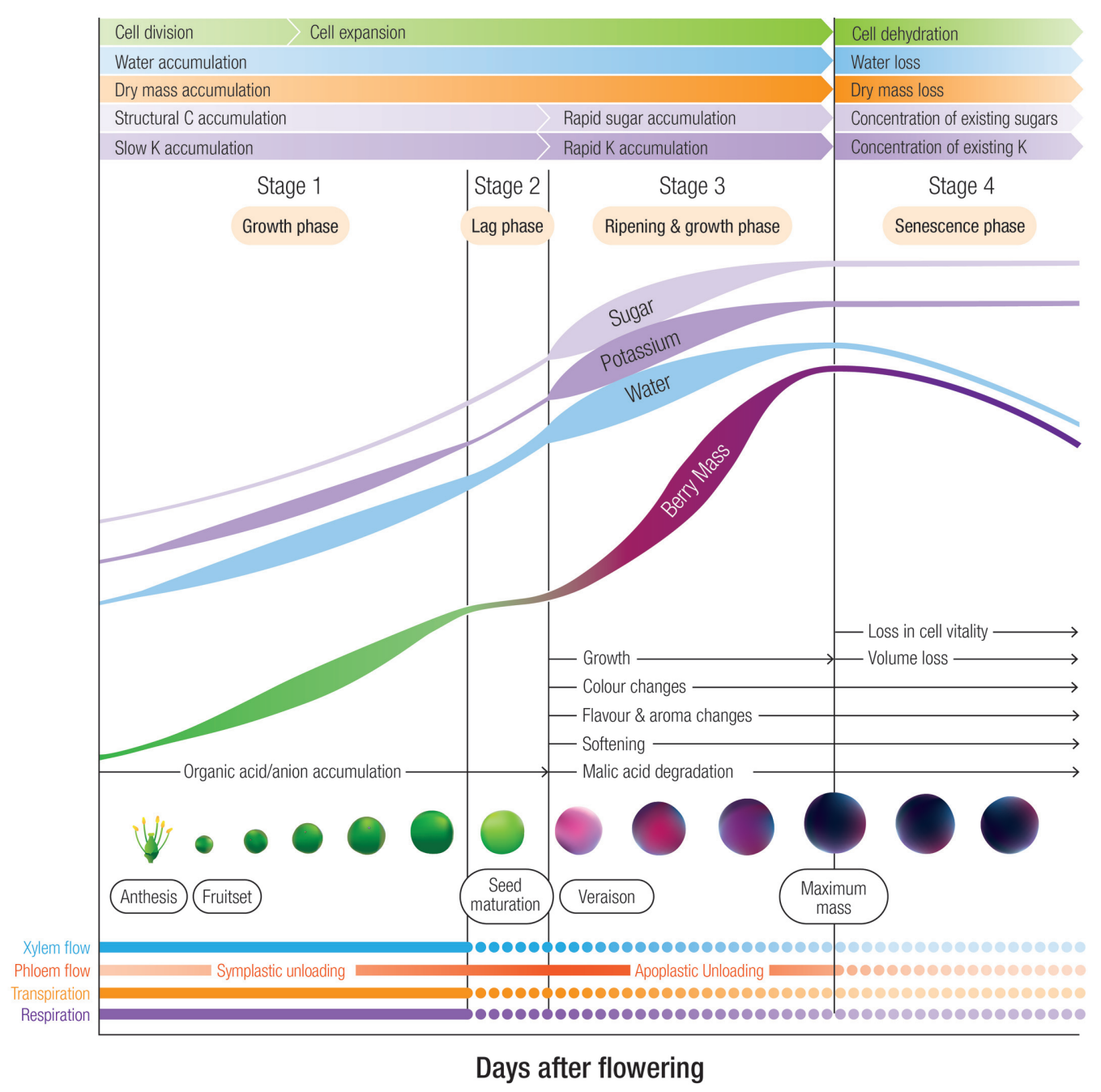

FIGURE 1 | The four developmental stages of grape berries designating phases of rapid sugar, potassium and water accumulation. In Shiraz berries grown in a warm viticulture region of Australia, the lag phase occurs between 45 and 55 days after flowering, and maximum weight occurs at approximately 90 days after flowering. Stage 3 is associated with ripening and includes color, flavor and aroma changes, softening and malic acid degradation. Relative changes in cell division, cell expansion, dry mass, structural carbon accumulation, xylem and phloem flow, transpiration and respiration are also indicated.

\section{Cessation in $\mathrm{K}^{+}$Accumulation during Late Ripening}

As berries attain their maximum weight during the later stages of ripening, $\mathrm{K}^{+}$accumulation slows. The cessation in phloem flow, and thus sugar and $\mathrm{K}^{+}$import into the berry may be related to an upper limit in the rising osmotic pressure within the vacuole (Patrick and Offler, 1996). The termination of phloem flow also coincides with the occurrence of cell death in the mesocarp. A loss of membrane integrity in mesocarp cells was initially proposed to begin at the onset of ripening (Lang and Thorpe, 1989; Lang and Düring, 1991). However, careful assessment of a number of varieties with vitality stains indicates it does not begin until late in ripening, initiating at the brush and the locular region near the seeds (Krasnow et al., 2008; Tilbrook and Tyerman, 2008; Clarke et al., 2010; Fuentes et al., 2010; Fontes et al., 2011). Even though the vascular tissues appear to remain vital (Tilbrook and
Tyerman, 2008), the breakdown in membrane integrity of the mesophyll cells may abolish the compartmentalization between the apoplast and symplast, flooding the apoplast with sugars. Thus the pressure gradient that drives phloem flow is abolished and $\mathrm{K}^{+}$accumulation is arrested.

\section{$\mathrm{K}^{+}$Transporters and Channels}

In plants, the uptake of $\mathrm{K}^{+}$across the membrane is facilitated by channels and transporters either of which can be high or low affinity, and sometimes both (for a full description see Gierth and Mäser, 2007; Alemán et al., 2011; Mitra, 2015). In brief, the channels consist of three families: Shaker type channels, KCO channels and cyclic nucleotide-gated channels (Véry and Sentenac, 2002). These voltage-gated channels are involved in $\mathrm{K}^{+}$uptake from the soil, long distance $\mathrm{K}^{+}$transport in the xylem and phloem and $\mathrm{K}^{+}$fluxes in guard cells. They 
may be inwardly rectifying (allowing an inward flux of $\mathrm{K}^{+}$ into the cell) or outwardly rectifying (allowing a $\mathrm{K}^{+}$outward efflux) based on their voltage dependence of open probability. There are also non-selective cation channels, the molecular identity of which has yet to be determined, though there are many candidates including some aquaporins (Byrt et al., 2016). The transporter category includes $\operatorname{TrK} / \mathrm{HKT}\left(\mathrm{Na}^{+} / \mathrm{K}^{+}\right.$ symporter) transporters (Schachtman, 2000), KUP/HAK/KT $\left(\mathrm{H}^{+} / \mathrm{K}^{+}\right.$symporter) transporters (Kim et al., 1998), an $\mathrm{K}^{+} / \mathrm{H}^{+}$ antiporter homolog (Bassil and Blumwald, 2014), and glutamate receptors (Véry and Sentenac, 2002). Most studies have been on Arabidopsis or rice, and roots have received considerable attention given their importance in $\mathrm{K}^{+}$uptake (Chérel et al., 2014; Chen et al., 2015). Studies are, however, emerging on economically important fruit species with an emphasis on the reproductive tissues. KUP gene expression was assessed during peach development and two of these, PpeKUP1 and PpeKUP2, mediated $\mathrm{K}^{+}$uptake during the rapid fruit expansion phases of this climacteric fruit (Song et al., 2015). A recent study on the non-climacteric strawberry, also from the Rosaceae, reported the cloning of a $\mathrm{K}^{+}$channel gene, FaKAT 1 with homology to the Arabidopsis $K A T_{1}$ and inducible by ABA (Song et al., 2017). Transcripts were expressed in stems, leaves and fruit, increased with ripening and were coupled to the formation of the red color in the flesh.

Like other fruit species, the study of $\mathrm{K}^{+}$channels and transporters in grapevines is still in its infancy, however, to date, three Shaker channels and two KUP/HAK/KT transporters have been cloned and characterized (Pratelli et al., 2002; Davies et al., 2006; Hanana et al., 2007; Cuéllar et al., 2010, 2013). A Shaker channel, SIRK, is expressed at low levels prior to veraison in the berry pericarp and then is undetectable after the onset of ripening (Pratelli et al., 2002). The two KUP/HAK/KT transporters are also expressed highly in skins of pre-veraison berries (Davies et al., 2006). The only $\mathrm{K}^{+}$uptake system identified thus far that is upregulated at véraison is a Shaker channel (VvK1.2) expressed in the plasma membrane of mesocarp and phloem tissues (Cuéllar et al., 2013). These channels and transporters are described in the relevant sections below.

Co-expression of genes during berry development may provide information on the functional links between proteins. It is possible to examine the gene expression networks from published transcriptomes obtained at different stages of development using tools such as Cytoscape (Shannon et al., 2003). Compiled networks are also available (e.g., Wong et al., 2013). Genes expressed during ripening of Shiraz berries were obtained by Sweetman et al. (2012) using RNAseq. They defined clusters of expression patterns based on expression relative to the key development stage of veraison when rapid sugar and potassium accumulation begins. Similar data sets can also be obtained for other varieties (e.g., Palumbo et al., 2014), but Sweetman et al. (2012) provide more samples at around veraison and have conveniently categorized clusters associated with veraison. Using the Sweetman et al. (2012) data set and extracting all known transporter genes it is possible to then examine co-expression networks on or near veraison. Figure 2 details three networks extracted using the
Cytoscape plugin ExpressionCorrelation. Shown are only the positive interactions with high Pearson Correlation Coefficients $(>0.98)$ based on the premise that for $\mathrm{K}^{+}$and sugar to accumulate the expression of the transporters should be both upregulated at a similar time in development. This does not allow for the possibility of a negative regulator of protein function such as a kinase or phosphatase that were not included in the set of genes use for this analysis, and which are known to regulate transporters. The preliminary analysis shown simply demonstrates the possible genes that could be further examined in detail. Of the set shown some are highly expressed, for example SWEET15 (bidirectional sugar transporter) and various aquaporins. There are several possibilities for $\mathrm{K}^{+}$ transport including members of the KUP/HAK/KT family, AKT, cation $/ \mathrm{H}^{+}$antiporters and CNGCs. The most highly expressed $\mathrm{K}^{+}$transporter that did not come out of this analysis is AKT2/3, which is upregulated in early veraison (Sweetman et al., 2012) and does have a positive interaction with SWEET10, SWEET2 and SWEET 14.

\section{$\mathrm{K}^{+}$AS AN OSMOTICUM}

\section{Cell Expansion and Growth}

Grape berry growth has two distinct growth phases separated by a lag phase (Sadras and McCarthy, 2007). Rapid cell division shortly after fruit set drives cell number and the potential size of the fruit (Coombe and Iland, 2004). However, cell expansion during the majority of stage I and during stage III is the major determinant of berry size and this is mainly due to water accumulation since berries typically contain 75-85\% water. Aquaporins are major intrinsic proteins that facilitate the flow of water across membranes and are responsible for most of the hydraulic conductivity of the plasma membrane and tonoplast (Tyerman et al., 2012). Two plasma membrane intrinsic proteins (PIP1 and PIP2) were highly expressed in berries after veraison, corresponding to the period of greatest hydraulic conductivity (Choat et al., 2009). This agrees with earlier results by Picaud et al. (2003) and further functional characterisation will shed light on these processes.

Aquaporins are an important mechanism for controlling water flow through tissues and cells, however, there are still important uncertainties that need to be resolved concerning those key processes that drive water accumulation into berry pericarp cells. It has been suggested that the rapid increase in solute accumulation within the ripening grape berry mesocarp, including sugars, organic acids, $\mathrm{K}^{+}$and other cations such as $\mathrm{Mg}^{2+}$, drives osmotic water influx (Mpelasoka et al., 2003). The resulting increase in turgor then extends the cell wall and drives growth (Serpe and Matthews, 2000). While other univalent cations can take over this role, most of them (e.g., $\mathrm{Na}^{+}$and $\mathrm{NH}_{4}{ }^{+}$) are toxic at high concentrations or not naturally available (e.g., $\mathrm{Rb}^{+}$).

A role for $\mathrm{K}^{+}$in driving cell expansion is evident in root hair elongation (Rigas et al., 2001), cotton fiber elongation (Ruan et al., 2001) and Arabidopsis shoot expansion (Elumalai 


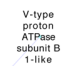
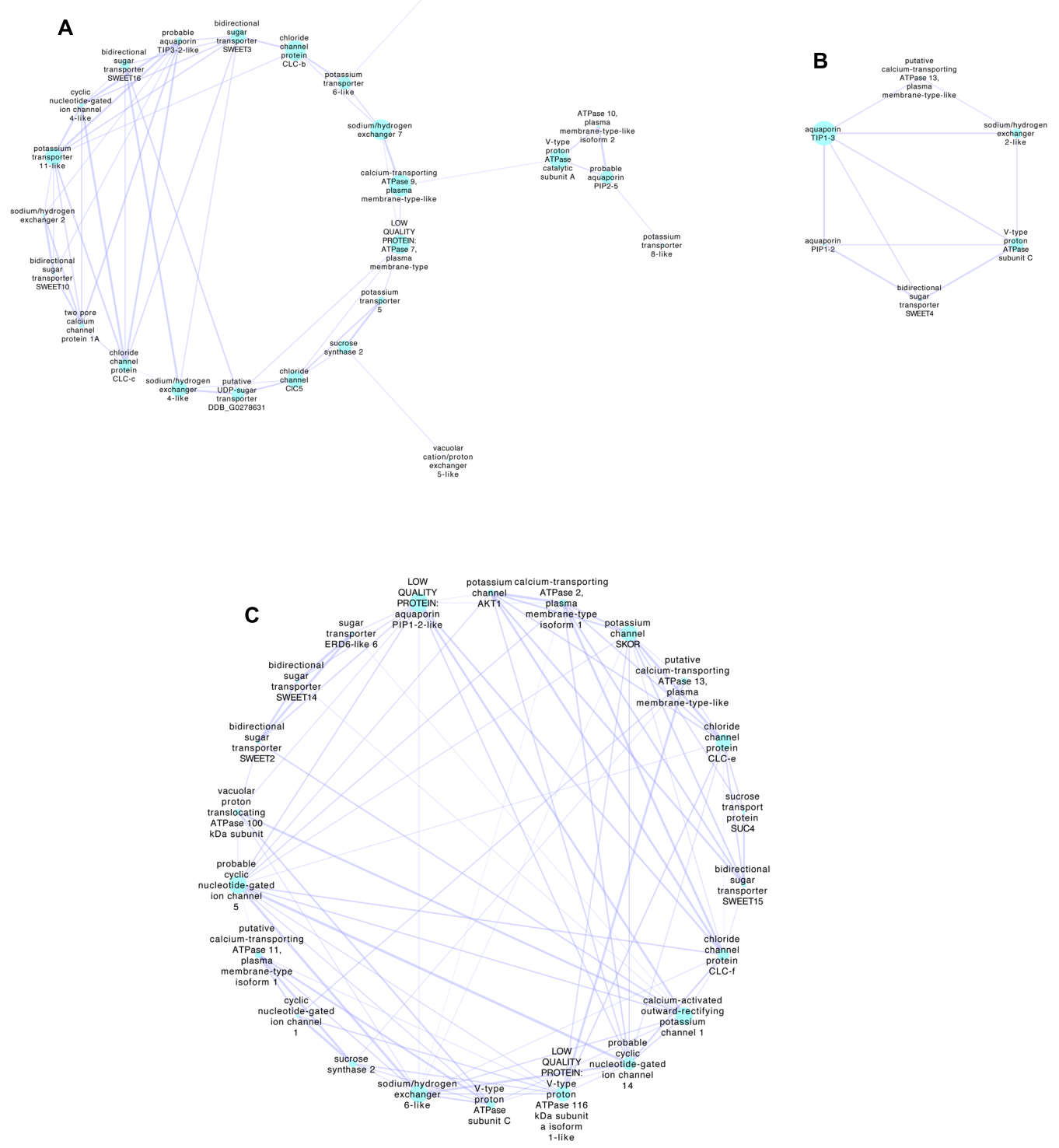

FIGURE 2 | Transporter-gene expression networks for Shiraz berries during development associated with veraison. The networks were obtained using Cytoscape 3.5.1 (http://www.cytoscape.org/index.html) (Shannon et al., 2003) with the RNAseq data of Sweetman et al. (2012), where all transporter genes plus sucrose synthases and invertases were selected giving a total of 260 detected transcripts. Those with very low expression (value of zero during any stage) or those without an associated Genoscope identification were excluded giving a total of 188 transcripts that were log (Ln2) transformed before analysis with Cytoscape (ExpressionCorrelation plugin). Using the classifications of clusters determined by Sweetman et al. (2012), nodes were selected as Early veraison or Veraison up-regulated or Veraison onwards. Networks were then generated from the first nodes connected to these selected clusters using only positive interactions with better than 0.98 (Pearson Correlation Coefficient). Three networks were extracted as shown. (A,B) Networks associated predominately with Veraison upregulated or Early veraison, (C) Network associated with Veraison onwards that includes the Sweetman et al. (2012) cluster Increasing. The size of the nodes indicates the Betweenness Centrality of the node indicative of how central the node is in the overall network. The thickness of the edges (lines connecting the nodes) indicates the strength of the positive relationship. Selected highly expressed transcripts related to sugar transport and cation transport, in each network include; (A) bidirectional sugar transporter SWEET10 (SWEET10 VIT_17s0000g00830), cyclic nucleotide-gated ion channel 4-like (ATCNGC4 VIT_19s0014g03700), sodium/hydrogen exchanger 2(NHX4 VIT_05s0020g01960) and potassium transporter 11-like (KUP11 VIT_01s0011g01510). The most highly expressed gene is probable aquaporin PIP2-5 (PIP2;3 VIT_08s0040g01890). (B) Sodium/hydrogen exchanger 2-like (VIT_14s0128g00020), bidirectional sugar transporter SWEET4 (VIT_02s0025g02080). The most highly expressed gene is aquaporin PIP1-2 (PIP1;3 VIT_02s0025g03390). (C) Bidirectional sugar transporter SWEET15 (SAG29, VIT_01s0146g00260), probable cyclic nucleotide-gated ion channel 5 (VIT_11s0037g00230), chloride channel protein CLC-f (CLC-F VIT_19s0015g01850). The most highly expressed gene is sucrose synthase 2 (VIT_07s0005g00750). Gene IDs (in brackets) were found by blasting nucleotide sequence from the Vitis vinifera 8x assembly (From Genoscope ID provided by Sweetman et al. (2012)) then blasting this nucleotide sequence against the Vitis vinifera IGGP_12x in Ensembl Plants. Annotations provided by Sweetman et al. (2012) are in italics. 
et al., 2002; Apse et al., 2003; Barragán et al., 2012). Rootstock studies in grapevines demonstrated a strong positive correlation between vine vigor and berry $\mathrm{K}^{+}$(Walker and Clingeleffer, 2009). In the grape berry, KUP/KT/HAK type VvKUP1 and VvKUP2 $\mathrm{K}^{+}$transporters considered by Davies et al. (2006) showed higher activity during flowering and pre-veraison than post-veraison. Expression was emphasized in the exocarp and so these transporters may be responsible for driving vacuolar expansion in this berry compartment. Continued low expression during the ripening phase indicates that it may contribute to $\mathrm{K}^{+}$homeostasis (Martins et al., 2012). The inward-rectifying SIRK channel identified by Pratelli et al. (2002) was expressed in berry guard cells and possibly the xylem at low levels prior to veraison and it was suggested it may be responsible for guard cell regulation and berry water relations at this early stage. In contrast, a vacuolar cation $/ \mathrm{H}^{+}$antiporter encoded by the gene VvNHX1, characterized by Hanana et al. (2007), was found to be expressed in the mesocarp and exocarp cells at high levels during veraison and after veraison. Vacuolar $\mathrm{H}^{+}$pumps are responsible for driving the accumulation of inorganic ions, organic anions and sugars by establishing an electrochemical proton gradient (Terrier et al., 2001). It was suggested that VvNHX1 has an important role in vacuolar expansion and mediates $\mathrm{K}^{+}$vacuolar accumulation to drive water entry into the berry cells. The authors went on to clarify that the rapid accumulation of reducing sugars also contributes to the process of generating turgor and driving cell expansion (Hanana et al., 2007). We suggest that under low sugar conditions in the pre-veraison berry, $\mathrm{K}^{+}$probably serves as the predominant osmoticum to drive cell expansion (Lang and Thorpe, 1989; Huang and Huang, 2001). After veraison, however, sugar loading into the mesocarp vacuoles is rapid and can be 10 - fold greater than $\mathrm{K}^{+}$concentrations. $\mathrm{K}^{+}$may be a minor contributor to fruit osmotic potential even after veraison, despite occurring at a 10 -fold lower concentration relative to the sugars. This is in part because every $\mathrm{K}^{+}$ion requires a complementary negative ion to maintain a balanced charge and these also contribute to the osmotic gradient. The higher $\mathrm{K}^{+}$concentration that is evident in grape exocarp cells, as outlined above, may be related to its osmotic role. The peripheral bundles are located just beneath the exocarp and it would be expected that the apoplastic sugar concentrations are high in this region due to phloem unloading. $\mathrm{K}^{+}$may be required at higher concentrations in the skin vacuoles to counterbalance the strong osmotic pressure of the apoplast. Further work examining the relative contributions of the typical solutes within post-veraison grape berry mesocarp and exocarp cells is required to determine the importance of $\mathrm{K}^{+}$in driving cell expansion prior to and after veraison.

\section{Regulation of Berry Turgor}

$\mathrm{K}^{+}$may have other roles in the berry related to developmental changes in fruit turgidity. Changes in fruit softness and texture during ripening may attract birds and aid in seed dispersal. From a physiological perspective, the mesocarp cells of ripe berries tend to be less turgid than their younger counterparts, presumably to prevent berries from splitting under high soil water availability and low evaporative demand (Matthews and Shackel, 2005; Thomas et al., 2006; Clarke et al., 2010). Moreover, immature green berries tend to swell and shrink diurnally in accordance with plant water status (Lang and Thorpe, 1989), while ripe berries tend to be less sensitive to daily swings in plant water status (Greenspan et al., 1994; Matthews and Shackel, 2005). This uncoupling of plant from fruit water potential may be the result of the accumulation of solutes within the apoplast. Using a modified centrifugation technique, Wada et al. (2008) found that apoplast solute potential decreased from $-0.2 \mathrm{MPa}$ to $-4.0 \mathrm{MPa}$ from early to late in development and a number of solutes within this extract, including $\mathrm{K}^{+}$, increased markedly prior to veraison. Accordingly, Caravia et al. (2015) noted altered apoplast impedance in Shiraz berries during the later stages of ripening, decreasing proportionally with the extent of cell death. Even though post-veraison berries accumulated more fructose and glucose, $\mathrm{K}^{+}$, as a very mobile solute, may also reduce the apoplastic tension, but this is likely to be variety dependent.

\section{Backflow}

The occurrence of shriveling as found in fully mature Shiraz berries on vines grown in warm climates (Coombe and McCarthy, 2000) has been attributed to reduced xylem and phloem flows into the berry in combination with ongoing transpiration and possibly backflow (Tyerman et al., 2004; Keller et al., 2006). Water flow in the reverse direction from fruit to leaves via xylem backflow has been demonstrated using tracers in kumquat (Mantell et al., 1980) and through water budget calculations in apple (Lang, 1990) and cv. Italia grapes (at $50 \mathrm{~mm}^{3} \mathrm{day}^{-1}$, Lang and Thorpe, 1989) after pedicel girdling. Backflow was also occasionally apparent in post-veraison water stressed Cabernet Sauvignon berries during the day (Greenspan et al., 1994). Moreover, using fluorescent dyes, Tilbrook and Tyerman (2009) were able to provide compelling evidence by visually demonstrating backflow from Shiraz grapes to pedicels during the shriveling phase. Further evidence for backflow was sought through xylem pressure measurements in Shiraz. Rather than the expected very negative pressures within the berry xylem after veraison in berries with low osmotic potentials, xylem pressures approaching zero were evident and it was suggested that this may be the result of high concentrations of apoplastic solutes brought about by a loss in membrane selectivity (Tyerman et al., 2004; Tilbrook and Tyerman, 2008; Choat et al., 2009; Hocking et al., 2016). Because the sugars are close to equilibrium across the plasma membrane, $\mathrm{K}^{+}$ may account for what little turgor there is. Alternatively, $\mathrm{K}^{+}$ may be one of those apoplastic solutes that plays a role in the abolition of the pressure gradient. Incidentally, backflow leading to berry shrinkage is not necessarily a negative attribute from an applied perspective. It decreases yield but it can concentrate flavor and aromas which is potentially desirable depending on the intended final wine style. Nonetheless, given the implications of backflow for berry turgidity, yield, composition, and potentially phloem water recirculation, further studies characterizing factors and conditions driving reverse water flow are well deserved. 


\section{Pollen Tube Growth}

Because of $\mathrm{K}^{+}$'s ability to behave as an osmoticum, this cation has control over pollen hydration and pollen tube growth to the ovary (Fan et al., 2001; Rehman et al., 2004) and therefore the success of pollination and fertilization of the ovule. A Shaker $\mathrm{K}^{+}$channel, mediating inward $\mathrm{K}^{+}$channel activity, expressed in Arabidopsis pollen and in the growing pollen tube confirmed the importance of $\mathrm{K}^{+}$to pollen competitive ability (Mouline et al., 2002; Zhao et al., 2013). Grape flowers are self-pollinated (Lavee and Nir, 1986) and the anthers often burst shortly before the dehiscence of the calyptra, allowing deposit of the pollen grains on the receptive stigma (May, 2004). The moist surface of the stigma then encourages pollen hydration and the formation of the pollen tube (Meneghetti et al., 2006). $\mathrm{Ca}^{2+}$, auxin and GA based signaling stimulate the process with the aid of energy from starch degradation (Gillaspy et al., 1993; Taylor and Hepler, 1997; FranklinTong, 1999). The 1000-fold elongation and very rapid rates of pollen tube extension $(10.7 \mu \mathrm{m} / \mathrm{min})$ (Staudt, 1982) would suggest that an osmoticum is responsible for the turgor-driven process. Moreover, once the ovule is reached, the rupture of the pollen tube tip to release the sperm cells is driven by a rapid increase in pressure (Staudt, 1982). Given the role of $\mathrm{K}^{+}$as an osmoticum in pollen tube growth of Arabidopsis, $\mathrm{K}^{+}$may, accordingly, have a similar function in grape pollen. Consequently, aside from environmental factors resulting in poor pollen germination (Ebadi et al., 1995), poor fruit set in grapes may also be the result of inadequate $\mathrm{K}^{+}$nutrition or $\mathrm{K}^{+}$partitioning to the flower pollen. Moreover, salinity reduced pollen tube growth in grapevines (Baby et al., 2016) and this might be the result of reduced $\mathrm{K}^{+}$uptake under high $\mathrm{Na}^{+}$ (Botella et al., 1997).

\section{Berry Stomatal Control}

$\mathrm{K}^{+}$in guard cells is important for regulating the aperture of stomata. $\mathrm{K}^{+}$is accumulated into the guard cell and this draws in water from the surrounding cells, opening the stomata (Nguyen et al., 2017). $\mathrm{K}^{+}$channel activity is known to be regulated by $\mathrm{ABA}$ in guard cells in a $\mathrm{Ca}^{2+}$ dependent (Köhler et al., 2003) or independent (Blatt, 2000) manner. $\mathrm{K}^{+}$is thus critical for regulating $\mathrm{CO}_{2}$ supply and plant water loss. Grape berries also harbor stomata but at a much lower frequency than the leaves, and as the fruit grows their frequency declines even further and they evolve into non-functional lenticels occluded by wax (Blanke, 1986; Rogiers et al., 2004). Nonetheless, early in development, stomata appear to be functional (Blanke and Leyhe, 1987; Breia et al., 2013) and it was estimated that fruit photosynthesis supplies $10 \%$ of the carbon required for fruit development (Ollat and Gaudillère, 2000). The grapevine Shaker channel VvSIRK (stomatal inward rectifying $\mathrm{K}^{+}$channel) identified by Pratelli et al. (2002) has a promotor that is expressed in active guard cells. SIRK transcript quantities were higher pre-veraison, decreasing drastically by the time of veraison likely due to the conversion of the stomata into the non-functional lenticels (Pratelli et al., 2002).

\section{The Role of $\mathrm{K}^{+}$in Phloem Transport}

The growth and maintenance of plant tissues is dependent on the translocation of newly fixed photoassimilates from sources (the sites of synthesis, e.g., mature leaves) to the sinks (the sites of consumption or storage, e.g., roots and berries). An osmotic potential gradient is generated through the loading of solutes into the sieve tubes at the source and unloading at the sink, resulting in a water gradient and a mass flow up to $1 \mathrm{~m} \mathrm{~h}^{-1}$ (Tyree and Fensom, 1970; Daudet et al., 2002; Thompson and Holbrook, 2003). This is referred to as the Münch theory and applies to most plant systems. A modification to this hypothesis 'the turgor-regulated translocation hypothesis' has been proposed for grape berries (Lang, 1983; Lang and Thorpe, 1986; Lang and Düring, 1991) where a loss in cell membrane integrity and thus cellular compartmentation at veraison results in apoplasmic osmotic pressure gradients. However, as evidenced by the uptake of fluorescent sugars, membranes do remain intact through most of ripening (Krasnow et al., 2008; Fontes et al., 2011) and it has been suggested that this hypothesis requires re-examination (Dai et al., 2010). Upon exiting the berry vasculature, the phloem solutes are deposited in the vacuoles of the mesophyll cells after traversing the tonoplast. Phloem unloading switches from a passive symplastic route (through plasmodesmata) in green berries to an apoplastic route (into the surrounding cell wall matrix) at veraison for at least one cultivar (Zhang et al., 2006), permitting ripening berries to accrue a high concentration of solutes without constraining phloem influx (Patrick, 1997). The switch to apoplastic unloading is apparent in other fruits that accumulate sugars such as the tomato (Ruan and Patrick, 1995) and apple (Zhang et al., 2004). Considerable progress has been made in understanding sugar accumulating processes into the grape mesocarp cells (Davies et al., 2012). Sucrose is the chief form in which sugar is transported through the phloem and this is hydrolysed by acid or neutral invertases, or sucrose synthase, to glucose and fructose either at or some point beyond the sieve element/companion cell (se/cc) boundary (Davies and Robinson, 1996). Both sucrose transporters (Ageorges et al., 2000; Manning et al., 2001; Zhang et al., 2008) and hexose transporters (Fillion et al., 1999; Vignault et al., 2005; Conde et al., 2006; Hayes et al., 2007; Jaillon et al., 2007) have been identified in grapevines.

Improving our understanding of phloem transport processes has applied relevance because the sugar-acid balance of fruit is one of the main determinants for wine quality. Cooler regions often struggle with low sugar in berries, however, recent problems with excess sugar concentration in warm regions due to climate warming leads to excessively high alcohol. This combined with losses in acidity due to malate degradation and rapid $\mathrm{K}^{+}$ accumulation may result in wines with undesirable organoleptic qualities.

\section{Phloem Loading}

$\mathrm{K}^{+}$transport in the phloem is generally from older tissues to growing organs such as new leaves and developing fruits 
(Mengel and Kirkby, 1987). Much attention has been given to sucrose loading and membrane energization by proton pumping in the phloem at the point of collection (source) (Lacombe et al., 2000), and this has revealed that $\mathrm{K}^{+}$can stimulate sucrose loading in a number of species (Schobert et al., 1998). Accordingly, $\mathrm{K}^{+}$deficiency can result in leaf sugar accumulation and it has been suggested this is due to, along with reduced starch synthase activity, reduced phloem loading and impaired sucrose export (Vreugdenhil, 1985; Cakmak et al., 1994; Zörb et al., 2014). A role for $\mathrm{K}^{+}$channels was apparent in an Arabidopsis knock-out mutant of the AKT2/3 $\mathrm{K}^{+}$channel where sucrose loading and sieve element sucrose concentration was reduced (Deeken et al., 2002). Likewise, the putative sucrose transporter ZmSUT1 mediated sucrose $/ \mathrm{H}^{+}$symport in the phloem of Zea mays, while the phloem $\mathrm{K}^{+}$channel ZMK2 was able to stabilize the membrane potential during phloem loading processes and KZM1 channel mediated $\mathrm{K}^{+}$uptake (Philippar et al., 2003). Phloem loading processes have received little attention in grapevines and it has not yet been established if the mechanism is passive symplastic, active apoplastic or a combination shifting with development or environmental cues. The simultaneous increase in sucrose and $\mathrm{K}^{+}$unloading from the phloem during ripening would suggest that the loading of these two solutes in the leaf minor veins are closely linked.

In some species, however, it has been observed that $\mathrm{K}^{+}$ enters the se/cc when sugars are low and exits the se/cc when sugars are high (Smith and Milburn, 1980a,b; van Bel and Hafke, 2005) and this has led to the compensatory potassium uptake theory (van Bel and Hafke, 2005). The observation that increased canopy shading results in grape berries with lower sugar but greater $\mathrm{K}^{+}$content (Smart et al., 1985; Archer and Strauss, 1989; Rojas-Lara and Morrison, 1989; Dokoozlian and Kliewer, 1996; dos Santos et al., 2007) might be explained by the compensatory theory, triggered under sub-optimal light and photosynthesis.

\section{Long-Distance Phloem Transport and Retrieval}

Because $\mathrm{K}^{+}$is the predominant mineral nutrient within the phloem sap of many species, including grapevines, it, regulates the osmotic potential of the phloem sap and thus phloem flow rates (Marschner, 1995). The mechanisms of phloem and $\mathrm{K}^{+}$transport in grapevine have been poorly investigated despite evidence that this cation and its charge balancing anions contribute to the hydrostatic pressure gradient between the collection and the release phloem (Lang, 1983). $\mathrm{K}^{+}$and its associated anions have been hypothesized to maintain the hydraulic pressure gradient along the phloem pathway in Arabidopsis (Deeken et al., 2002) and Vicia faba (Ache et al., 2001). The long distance pathway between the source and sink is relatively leaky and the solutes require retrieval and reloading to maintain the chemiosmotic gradient (Minchin and Thorpe, 1987; Hafke et al., 2005). While some of the sucrose is used to nourish the surrounding tissues and sinks, the rest is reloaded in a mechanism similar to loading at the source. Recent work in
Arabidopsis has resulted in an hypothesis wherein $\mathrm{K}^{+}$circulating within the phloem may serve as a decentralized energy store to overcome local energy limitations (Gajdanowicz et al., 2011). $\mathrm{K}^{+}$is loaded in source tissues and then transported along the phloem stream to areas deficient in $\mathrm{K}^{+}$. After passage through a $\mathrm{K}^{+}$channel, $\mathrm{K}^{+}$may assist plasma membrane $\mathrm{H}^{+}$-ATPases to re-energize the transmembrane phloem loading process, such as in the retrieval of leaked sucrose.

A role for $\mathrm{K}^{+}$was also suggested in a somewhat different perspective on the mechanics of long distance phloem transport. Because sieve pores are partly covered with proteins, the narrow pores create a pressure drop across the sieve plate (van Bel and Hafke, 2005). To counteract this, sucrose may be released into the sieve tube apoplast at the proximal end of the sieve tube and retrieved at the distal end (van Bel and Hafke, 2005). Sucrose/ $\mathrm{H}^{+}$ symport induced depolarization of the plasma membrane of the se/cc can be rectified by $\mathrm{K}^{+}$channels in order to maintain the proton gradient for sucrose uptake (van Bel and Hafke, 2005).

An alternative hypothesis for $\mathrm{K}^{+}$accumulation into grape berries is related to $\mathrm{K}^{+}$'s role as an osmotic facilitator for phloem transport. Unlike sucrose, $\mathrm{K}^{+}$plus anions have low viscosity at high concentration, and perhaps facilitate the flow of phloem sap which would be too viscous with sucrose alone (Thompson and Zwieniecki, 2005). This hypothesis could explain the consistent and rapid simultaneous unloading of $\mathrm{K}^{+}$and sugars into the grape berry.

\section{Phloem Unloading}

Finally, $\mathrm{K}^{+}$may have a role in phloem unloading of sugar. Prior to veraison, most of the imported sugar is metabolized and phloem unloading occurs via a symplasmic route. However, once ripening begins the sugars are stored in the vacuole and the sugar-rich mesocarp cells become isolated from the se/cc complex so that phloem unloading can proceed despite the high concentration of sugars at the sink. After sucrose is unloaded from the se/cc complexes into the apoplasm at the point of release (sink) (Zhang et al., 2006), invertase in the cell wall cleaves sucrose into glucose and fructose and these are then transported across the plasma membrane and tonoplast with the aid of monosaccharide transporters (Agasse et al., 2009). Some sucrose may be cleaved by sucrose synthase in the cytosol or be taken up directly by disaccharide transporters in the vacuole and cleaved there (Davies et al., 2012). Aquaporins in the plasma membrane and tonoplast are highly expressed in expanding cells and upregulated simultaneously with sugar transporters (Figure 2). Therefore sugar and water transport may be linked (Fouquet et al., 2008) but little is known about how these transporters are interconnected with $\mathrm{K}^{+}$transport during ripening. The details of mineral transport across the plasma membrane and the tonoplast into the mesocarp cells are not yet well elucidated.

A link between sugar and $\mathrm{K}^{+}$unloading was established in the sinks of castor bean (Ache et al., 2001). The Shaker $\mathrm{K}^{+}$channel VFK1 was highly expressed in cotyledons, flowers, 
stem and sink leaves. Fructose induced VFK1 gene activity and the two-electrode voltage-clamp technique indicated that $\mathrm{K}^{+}$ controlled the electrical properties of the sieve tube plasma membranes. The proposed mode of unloading depicts that sucrose is released through a sucrose- $\mathrm{H}^{+}$antiport from the $\mathrm{se} / \mathrm{cc}$ and an apoplastic invertase converts the disaccharide into glucose and fructose. These are then taken up into the sink cell with a monosaccharide- $\mathrm{H}^{+}$symporter, lowering the apoplastic $\mathrm{H}^{+}$concentration and activating the $\mathrm{K}^{+}$channel. Other $\mathrm{K}^{+}$ channels and transporters also load $\mathrm{K}^{+}$into the sink cell (Ache et al., 2001). $\mathrm{K}^{+}$channels are linked to sugar unloading in castor bean (Ache et al., 2001), maize (Bauer et al., 2000) and Arabidopsis (Lacombe et al., 2000) and similar lines of evidence have recently been established at the molecular level in grapevines (Cuéllar et al., 2013). An inward $\mathrm{K}^{+}$channel belonging to the Shaker family (VvK1.2 under control of specific $\mathrm{VvCIPK}-\mathrm{VvCBL}$ pairs) was expressed specifically in the plasma membrane of mesocarp and phloem tissues with a strong induction at veraison and thought to play a major role in $\mathrm{K}^{+}$transport (Cuéllar et al., 2013). It was stimulated by acidification of the external medium, and thus is likely regulated by apoplastic $\mathrm{pH}$ controlled by plasma membrane $\mathrm{H}^{+}$-ATPases. This channel may allow rapid $\mathrm{K}^{+}$retrieval from the apoplast by perivascular and mesocarp cells, decreasing the apoplastic concentration of this cation and thereby favoring its unloading from the se/cc complex. It was suggested that this unloading would stimulate phloem flux toward the sink and thus the accumulation of sugars into the berry (Cuéllar et al., 2013). Although this is feasible, apoplastic sugar unloading itself should stimulate phloem flux and it is uncertain why $\mathrm{K}^{+}$would also be required in this role. Perhaps a more likely scenario is that the $\mathrm{K}^{+}$channel stabilizes the membrane as a result of sugar- $\mathrm{H}^{+}$transporter activities, in a similar system as the castor bean. The accumulation of sugar and water into the vacuoles of mesocarp cells are undoubtedly linked but the function of $\mathrm{K}^{+}$in this complex process requires detailed assessment.

\section{Phloem Water Recirculation}

The unloading of phloem sap into the berry is expected to result in rapid water accumulation but due to low berry transpiration rates (Rogiers et al., 2004; Greer and Rogiers, 2009), it was proposed that the excess water is recycled to the plant through the xylem so that phloem flow is maintained (Keller et al., 2006, 2015). Even though flow through the xylem is reduced after veraison, it does not become hydraulically isolated and maintains the capacity to conduct water as indicated by dye (Keller et al., 2006), microscopy studies (Choat et al., 2009) and detailed hydraulic analysis (Scharwies and Tyerman, 2016). The reported increase in the osmotic pressure in the apoplast with ripening (Wada et al., 2008; Keller et al., 2015) was attributed to the accumulation of hexoses and organic anions, mainly those of malate and tartrate (Keller and Shrestha, 2014) despite the predominance of tartrate in the salt form during ripening (Iland and Coombe, 1988). $\mathrm{K}^{+}$, however, decreased in the apoplast of Concord and only contributed $4.6 \%$ in green berries and $2.7 \%$ in mature berries to the osmotic pressures of the apoplast (Keller and Shrestha, 2014), weakening the role for $\mathrm{K}^{+}$in the recycling of phloem water.

\section{$\mathrm{K}^{+}$AND PROGRAMMED CELL DEATH}

Reactive oxygen species (ROS) signaling networks may participate to the regulatory network of fruit development (Pilati et al., 2014) including programmed cell death (PCD) (Van Breusegem and Dat, 2006). At higher concentrations, ROS result in oxidative damage to proteins, lipids and other cellular components (Gadjev et al., 2008). The chloroplast and the mitochondrion are considered to be significant ROS generators but ROS are also produced in other locations within the cell including the plasma membrane, peroxisome and cell wall (Foyer and Noctor, 2003; Asada, 2006; O'Brien et al., 2012). ABA, an important regulator of grape berry development (Coombe and Hale, 1973; Wheeler et al., 2009), can at low concentrations induce antioxidative defense systems (Jiang and Zhang, 2001; Sakamoto et al., 2008); paradoxically, at high concentrations it can stimulate the production of $\mathrm{H}_{2} \mathrm{O}_{2}$ and increase lipid peroxidation (Jiang and Zhang, 2001).

Oxidative stress occurs in a number of fruits and similarly in the grape berry veraison is accompanied by an oxidative burst and the accumulation of $\mathrm{H}_{2} \mathrm{O}_{2}$ in the skin (Pilati et al., 2007). In order to cope with overproduced ROS, fruit have evolved defense mechanisms through the synthesis of phenolics, carotenoids, tocopherols, ascorbate, glutathione (DellaPenna and Pogson, 2006) and free radical enzyme scavenging systems (Rogiers et al., 1998; Sarry et al., 2004; Terrier et al., 2005; Pilati et al., 2014). Chloroplasts appear to be active during early fruit development in grapes, but once the photosynthetic apparatus degenerates (Palliotti and Cartechini, 2001), ${ }^{1} \mathrm{O}_{2}$ is likely to be generated in the resultant photooxidative conditions (Krieger-Liszkay, 2005). Consequently, analogous to leaves (Kim et al., 2010), $\mathrm{K}^{+}$may facilitate ROS mitigation in the chloroplasts of the berry skin early in ripening.

Mesocarp cell death occurs during late ripening in some grapevine cultivars (Tilbrook and Tyerman, 2008; Fuentes et al., 2010). It is characterized by a breakdown in cell membrane integrity and hypothesized to be the consequence of a form of PCD that contributes to the senescence of the berry. It may be a phenological stage integral to berry ripening and an adaptation to aid in seed dispersal. From a winemaking perspective, the loss in cell membrane integrity aids in juice extractability and may result in the formation of new secondary metabolites important for flavor and aroma (Tilbrook and Tyerman, 2008). The role of $\mathrm{K}^{+}$in these antioxidant systems at the fruit level has not yet received much attention. However, a decrease in the pool of cytosolic $\mathrm{K}^{+}$as a result of efflux through ROS-activated nonselective cation channels, has been linked to the activation of caspase-like proteases and PCD for plants grown under saline conditions (Shabala, 2009). 
Further work is required to determine if $\mathrm{K}^{+}$and ROS operate in an interlinked network regulating oxidative processes during berry development. Aside from PCD in the mesocarp, a large number of genes related to proteolysis and autophagy are also upregulated in the grape berry skin at this stage of ripening (Ghan et al., 2017). Research in this direction may be critical to control the process of ripening and senescence, via regulation of expression and operation of appropriate $\mathrm{K}^{+}$transporters in various berry tissues.

\section{$\mathrm{K}^{+}$, ROS AND PLANT STRESS}

$\mathrm{K}^{+}$is able to increase resistance to a number of environmental and biotic stresses because it contributes to the detoxification of ROS (Cakmak, 2005). Plants exposed to stresses such as intense light, drought, heat, cold or pathogens suffer from oxidative damage due to an imbalance between the production of ROS and the detoxification by the antioxidant scavenger system (Mullineaux and Baker, 2010). $\mathrm{K}^{+}$homeostasis is integral to the adaptation of plants to these abiotic and biotic stresses and the PCD that is often associated with them (Anschütz et al., 2014). At the plant level, low $\mathrm{K}^{+}$has been linked to an increase in ROS production, most often through impaired photosynthesis, in Arabidopsis (Kim et al., 2010) and a number of crops (Wang et al., 2013). In cotton, $\mathrm{K}^{+}$ deficiency resulted in premature leaf senescence as a result of higher $\mathrm{H}_{2} \mathrm{O}_{2}$ and malondialdehyde content (Hu et al., 2016). Genes related to peroxidase metabolism were down-regulated in pear grown under $\mathrm{K}^{+}$deficiency, indicating that under high $\mathrm{K}^{+}$, the accumulation of excessive oxygenated compounds was held in check by greater peroxidase activity (Shen et al., 2017). In grapevines, soil application of $\mathrm{K}^{+}$to plants grown under drought stress enhanced antioxidant enzyme activity in the leaves (Haddad and Kamangar, 2016). $\mathrm{K}^{+}$is able to inhibit ROS production under drought stress by maintaining photosynthetic electron transport and reducing NADPH oxidase activity (Cakmak, 2005).

Demidchik (2014) proposed that $\mathrm{K}^{+}$efflux through GORK channels may operate as a 'metabolic switch' to promote cell repair during stress such as salinity. Because $\mathrm{K}^{+}$activates numerous enzymes involved in normal cell metabolism (Zörb et al., 2014), its absence may deactivate them. This then allows the diversion of limited energy supplies to urgent defense metabolism (Shabala, 2017). It was suggested that this transient system may be appropriate for confined regions such as the root apex under stressful conditions, however, sustained low $\mathrm{K}^{+}$levels within the cytosol may result in PCD. We could extend this theory then to fruit and perhaps suggest a simple scenario where $\mathrm{K}^{+}$prevents PCD during late ripening by maintaining enzyme activity and thus normal cell metabolism. Could PCD then be triggered in late ripening by the efflux of $\mathrm{K}^{+}$and decreased cytosolic $\mathrm{K}^{+}$ levels?

\section{Berry $\mathrm{K}^{+}$and Drought Resistance}

The effects of drought stress on grapevine photosynthesis and water relations are well documented as are the consequences on berry development (Dry et al., 2001). Berry composition is determined by the severity and timing of the water stress with low water constraints often resulting in higher sugar concentrations and improved color through smaller berry size and thus an increase in the skin to flesh ratio (Roby and Matthews, 2004). Moderate to severe water stress, especially during ripening, can decrease berry size and sugar accumulation due to an inhibition of photosynthesis (Williams and Matthews, 1990). The consequences of water stress on berry $\mathrm{K}^{+}$concentrations are also likely a factor of its timing and severity (Etchebarne et al., 2009). In some instances, as demonstrated in irrigation studies, grapevines that do not receive irrigation have lower berry $\mathrm{K}^{+}$concentrations (Freeman and Kliewer, 1983; Hepner and Bravdo, 1985; Klein et al., 2000). $\mathrm{K}^{+}$uptake by plants is often diminished in drought due to reduced mobility in the soil and impaired root uptake (Tazawa et al., 2001; Hu and Schmidhalter, 2005; Osakabe et al., 2013). In tomato, a decrease in root hydraulic conductance and transpiration resulted from the down regulation of aquaporin and $\mathrm{K}^{+}$ channel transporter activity (Kanai et al., 2011), possibly as a mechanism to aid in water conservation (Smart et al., 2001).

Contrasting to the tomato system, the $\mathrm{K}^{+}$channel VvK1.1 of grapevines is expressed in root cortical cells and to a lesser extent in seed teguments of young berries and, although not developmentally regulated, this $\mathrm{K}^{+}$channel was markedly upregulated with drought and it was suggested it may play a major role in $\mathrm{K}^{+}$loading into berry tissues with water stress (Cuéllar et al., 2010). Likewise, VvK1.2 expression in the berry flesh, phloem tissues and perivascular cells of the vascular bundles was also enhanced by mild plant water stress. Drought stress induced a two- to threefold increase in gene expression of $\mathrm{VvK} 1.2$ at and post veraison, further substantiating that $\mathrm{K}^{+}$transport into berries is affected by drought stress (Cuéllar et al., 2013). Drought stressed plants may need additional $\mathrm{K}^{+}$and $\mathrm{K}$ fertilization improves water relations and osmotic adjustment in several plant systems (Shabala et al., 2016).

Similar to other plant systems (e.g., Shabala and Pottosin, 2014; Shabala et al., 2016), we suggest that greater $\mathrm{K}^{+}$ concentrations in berries decreases berry sensitivity to drought through ameliorating oxidative stress, controlling long-distance phloem transport and maintaining tissue turgor. When cells of any organism are exposed to hyperosmolality, they most often accumulate organic osmolytes such as sugar alcohols and amino acids. This is because organic osmolytes have compatibility with macromolecular structures and do not modify cellular proteins and protein function (Burg and Ferraris, 2008). In grapevines exposed to drought stress, leaf $\mathrm{K}^{+}$concentrations increased more so than organic solutes potentially because salt based osmotica have lower energetic costs (Patakas et al., 2002). Moreover, salts are used in organisms to respond quickly to osmotic shock (Galinski, 1995). Prior to their partial hydraulic isolation, pre-veraison berries are particularly sensitive to dehydration and $\mathrm{K}^{+}$plus associated anions may play a significant role in maintaining turgor. After veraison, it is likely that the organic osmolytes take on this predominant function because berries 


\section{Role of $K$ in vine, berry and cell function}

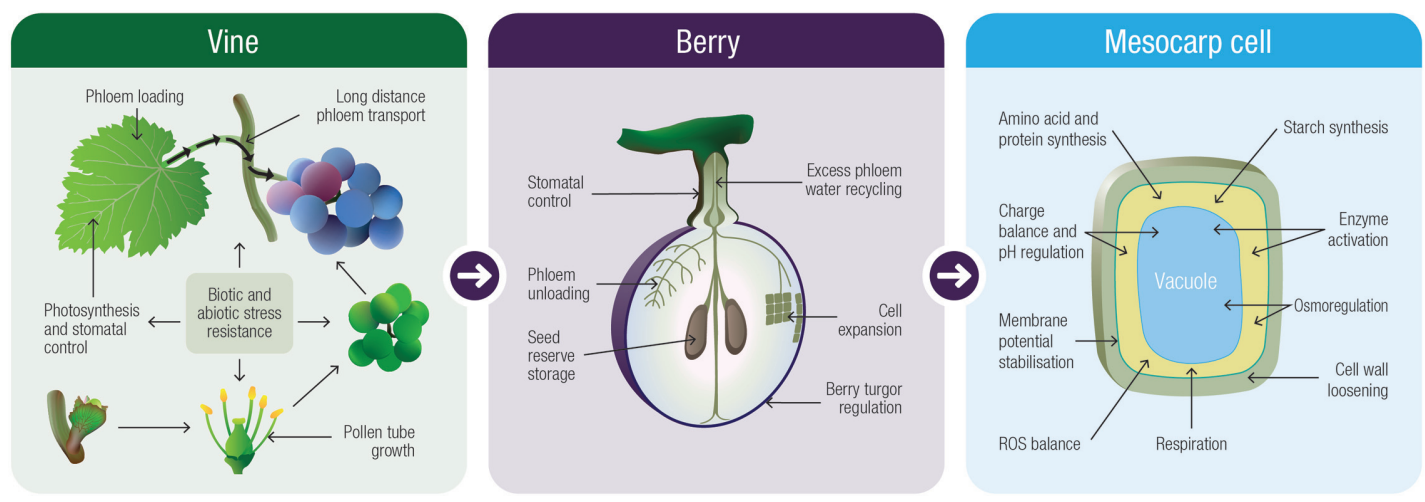

FIGURE 3 | A speculative model describing the functions of $\mathrm{K}^{+}$in the grapevine at the whole-plant, fruit and cellular level.

accumulate sugars at orders of magnitude greater concentrations than $\mathrm{K}^{+}$.

\section{$\mathrm{K}^{+}$and Frost Tolerance in Flowers}

Early spring growth in grapevines, that is to say, emerging shoots and inflorescences, are susceptible to frosts as are berries and leaves during autumn (Fennel, 2004). At the cellular level, frost damage is similar to water stress damage in that it leads to cellular dehydration due to ice formation. High concentrations of solutes can protect against freezing by lowering the freezing point of the apoplastic space and the cell solution (Thomashow, 1999). Flower tissues are particularly sensitive to frost and $\mathrm{K}^{+}$may be an important osmoticum at this early, susceptible stage of development. Indeed, as in other crops (Wang et al., 2013), sensitivity to frost damage declined with the availability of soil $\mathrm{K}^{+}$in grapevines (Eifert and Eifert, 1976). Aside from lowering the freezing point, $\mathrm{K}^{+}$ may also decrease frost sensitivity by limiting ROS production, especially as a result of impaired photosynthesis (Cakmak, 2005).

\section{$\mathrm{K}^{+}$and Biotic Stress Resistance}

Grape berries are particularly susceptible to insect and fungal attack (Nicholas et al., 1994). K-deficient plants of the major crop species tend to be more susceptible to infection; the addition of $\mathrm{K}$ fertilizer decreases insect infestation and disease incidence (Perrenoud, 1990). The critical roles of $\mathrm{K}^{+}$in primary metabolism ensure optimum berry health and that defense mechanisms are fully functioning. It has been proposed that $\mathrm{K}^{+}$encourages strong cell wall development and stimulates phenol production to prevent further infection (Wang et al., 2013). Moreover, the ability of $\mathrm{K}^{+}$to regulate stomatal closure is an important mechanism for warding off infections. The stomata and lenticels are significant entry points for fungi and bacteria, particularly on the rachis, pedicels, flowers and young berries (Whitelaw-Weckert et al., 2011) and proper closure of the guard cells upon their perception is essential to curtailing internal access (Melotto et al., 2006). $\mathrm{K}^{+}$has been implicated in the rapid response mechanism not only to infection but also herbivory-induced wounding because it is such a mobile element at the plant, tissue and cellular level (Marschner, 1995). Voltage regulated 'gated' $\mathrm{K}^{+}$channels are particularly useful in this regard as permeation rates through them are more than threefold faster than pumps and carriers (Tester, 1990).

\section{Viticultural Considerations}

From a viticultural perspective, information is required on the optimal $\mathrm{K}^{+}$concentrations in the berry at various stages of growth and development. Given the ability of $\mathrm{K}^{+}$to translocate from roots to leaves and then back to roots, the grapevine is an extremely responsive and adaptable system, capable of maintaining internal homeostasis and driving nutrient flow to areas of greatest demand. The paradox for the grower is to ensure that enough $\mathrm{K}^{+}$is available to maintain normal growth and berry functioning but simultaneously curtail increases in berry $\mathrm{pH}$ so that wine quality is maintained. Considering predicted increases in heat and drought periods within warm viticultural regions, as well as reduced water allocations, sustainable cost-effective management options are required. Mild water stress through irrigation strategies can be considered but is complex due to variety differences, climatic variations and soil variability; extreme care is thus required when considering irrigation as a management tool. Rootstocks such as those of the Vitis berlandieri parentage (Wolpert et al., 2005) and others (Walker and Clingeleffer, 2009; Walker and Blackmore, 2012) that are low $\mathrm{K}^{+}$accumulators show promise and require additional research attention. The interaction of $\mathrm{K}$ with other elements is complex and the use of $\mathrm{Ca}$ and $\mathrm{Mg}$ fertilization to reduce $\mathrm{K}^{+}$uptake has come up with inconsistent results (Hannan, 2011). Ca itself can have profound effects on berry development (Hocking et al., 2016). This is likely due to soil and climate interactions but does warrant further experimentation. All these approaches may also induce $\mathrm{K}^{+}$deficiency and thus precise recommendations are required that are based on real-time measurements of vine and 
also berry $\mathrm{K}^{+}$status. Finally, little attention has been given to the role of the bunch microenvironment on $\mathrm{K}^{+}$accumulation, mainly radiation, temperature, evaporative demand and wind speed. This is despite many studies confirming the role of the microenvironment on other attributes such as sugars (Dai et al., 2011), acidity (Sweetman et al., 2009), color (Matus et al., 2009) and aromas (Azuma et al., 2012).

\section{CONCLUDING REMARKS}

The basic functions of $\mathrm{K}^{+}$in the developing grape berry have received relatively little attention and there are many uncertainties and gaps in our knowledge. Nonetheless, by examining other plant systems for clues, we are able to build hypotheses on how this cation might influence and even direct fruit development. From Figure $\mathbf{3}$ it is evident that $\mathrm{K}^{+}$likely plays a number of roles that are integral to the development of the grape berry and this is one of the main messages that can be derived from this review. There is a large body of literature supporting the role for $\mathrm{K}^{+}$as an osmoticum in driving cell growth and maintaining tissue turgor. Therefore this cation is a likely candidate for driving mesocarp cell expansion in grape berries, especially prior to veraison when sugars are low. The intracellular and long-distance transport of $\mathrm{K}^{+}$, mediated by channels and transporters, is critical to fruit ripening but despite little research conducted along these lines in grapevines, some progress has been made. The specific functions for $\mathrm{K}^{+}$ in phloem transport is still a matter of debate, however, other crop systems do hint for a role in phloem loading, transport, sucrose retrieval and unloading. In this suggestive backdrop of

\section{REFERENCES}

Ache, P., Becker, D., Deeken, R., Dreyer, I., Weber, H., Fromm, J., et al. (2001). VFK1, a Vicia faba $\mathrm{K}^{+}$channel involved in phloem unloading. Plant J. 27, 571-580. doi: 10.1046/j.1365-313X.2001.t01-1-01116.x

Agasse, A., Vignault, C., Kappel, C., Conde, C., Gerós, H., and Delrot, S. (2009). "Sugar transport and sugar sensing in grape," in Grapevine Molecular Physiology and Biotechnology, ed. K. A. Roubelakis-Angelakis (Amsterdam: Springer), 105-139. doi: 10.1007/978-90-481-2305-6-5

Ageorges, A., Issaly, N., Picaud, S., Delrot, S., and Romieu, C. (2000). Identification and functional expression in yeast of a grape berry sucrose carrier. Plant Physiol. Biochem. 38, 177-185. doi: 10.1016/S0981-9428(00)00730-0

Ahmad, I., and Maathuis, F. J. (2014). Cellular and tissue distribution of potassium: physiological relevance, mechanisms and regulation. J. Plant Physiol. 171, 708-714. doi: 10.1016/j.jplph.2013.10.016

Alemán, F., Nieves-Cordones, M., Martínez, V., and Rubio, F. (2011). Root $\mathrm{K}^{+}$ acquisition in plants: the Arabidopsis thaliana model. Plant Cell Physiol. 52, 1603-1612. doi: 10.1093/pcp/pcr096

Almeselmani, M., Pant, R. C., and Singh, B. (2009). Potassium level and physiological response and fruit quality in hydroponically grown tomato. Int. J. Veg. Sci. 16, 85-99. doi: 10.1080/19315260903271526

Anschütz, U., Becker, D., and Shabala, S. (2014). Going beyond nutrition: regulation of potassium homoeostasis as a common denominator of plant adaptive responses to environment. J. Plant Physiol. 171, 670-687. doi: 10.1016/ j.jplph.2014.01.009

Apse, M. P., Sottosanto, J. B., and Blumwald, E. (2003). Vacuolar cation/ $\mathrm{H}^{+}$ exchange, ion homeostasis, and leaf development are altered in a T-DNA insertional mutant of AtNHX1, the Arabidopsis vacuolar $\mathrm{Na}^{+} / \mathrm{H}^{+}$antiporter. Plant J. 36, 229-239. doi: 10.1046/j.1365-313X.2003.01871.x information, further studies on the molecular determinants of $\mathrm{K}^{+}$ transport will undoubtedly provide answers to some of the critical physiological questions relating to long distance $\mathrm{K}^{+}$movement through the plant. Finally, $\mathrm{K}^{+}$has a clear role in biotic and abiotic stress resistance and may co-ordinate responses within the berry through control over ROS and osmotic homeostasis.

The grape berry is an ideal model for understanding the development of non-climacteric fruit due to its wide genetic diversity and ability to thrive in diverse environments. The studies summarized here show that the grape berry is rich in $\mathrm{K}^{+}$and its accumulation is dependent on developmental cues and environmental factors. Further research addressing the biochemical and molecular mechanisms regulating its uptake and partitioning from the sub-cellular to the whole plant scale will help us to gain a broader view of how to manage $\mathrm{K}$ in one of the most economically important fruit crops.

\section{AUTHOR CONTRIBUTIONS}

SR wrote the majority of the paper with input from ZC, RW, $\mathrm{AD}$, and ST. ST provided the data and figures for the Cytoscape analyses. All authors edited and commented on the manuscript.

\section{ACKNOWLEDGMENTS}

We acknowledge the ARC Training Centre for Innovative Wine Production (project No. IC130100005), with support from Wine Australia and industry partners.

Archer, E., and Strauss, H. C. (1989). Effect of shading on the performance of Vitis vinifera L. cv. Cabernet Sauvignon. S. Afr. J. Enol. Vitic. 10, 74-77.

Armengaud, P., Sulpice, R., Miller, A. J., Stitt, M., Amtmann, A., and Gibon, Y. (2009). Multilevel analysis of primary metabolism provides new insights into the role of potassium nutrition for glycolysis and nitrogen assimilation in Arabidopsis roots. Plant Physiol. 150, 772-785. doi: 10.1104/pp.108.133629

Asada, K. (2006). Production and scavenging of reactive oxygen species in chloroplasts and their functions. Plant Physiol. 141, 391-396. doi: 10.1104/pp. 106.082040

Azuma, A., Yakushiji, H., Koshita, Y., and Kobayashi, S. (2012). Flavonoid biosynthesis-related genes in grape skin are differentially regulated by temperature and light conditions. Planta 236, 1067-1080. doi: 10.1007/s00425012-1650-x

Baby, T., Collins, C., Tyerman, S. D., and Gilliham, M. (2016). Salinity negatively affects pollen tube growth and fruit set in grapevines and cannot be ameliorated by silicon. Am. J. Enol. Vitic. 67, 218-228. doi: 10.5344/ajev.2015.15004

Barragán, V., Leidi, E. O., Andrés, Z., Rubio, L., De Luca, A., Fernández, J. A., et al. (2012). Ion exchangers NHX1 and NHX2 mediate active potassium uptake into vacuoles to regulate cell turgor and stomatal function in Arabidopsis. Plant Cell 24, 1127-1142. doi: 10.1105/tpc.111.095273

Bassil, E., and Blumwald, E. (2014). The ins and outs of intracellular ion homeostasis: NHX-type cation/ $\mathrm{H}^{+}$transporters. Curr. Opin. Plant Biol. 22, 1-6. doi: 10.1016/j.pbi.2014.08.002

Bauer, C. S., Hoth, S., Haga, K., Philippar, K., Aoki, N., and Hedrich, R. (2000). Differential expression and regulation of $\mathrm{K}^{+}$channels in the maize coleoptile: molecular and biophysical analysis of cells isolated from cortex and vasculature. Plant J. 24, 139-145. doi: 10.1046/j.1365-313X.2000.00844.x

Blanke, M. M. (1986). Comparative SEM study of stomata on developing quince, apple, grape and tomato fruit. Angew. Bot. 60, 209-214. 
Blanke, M. M., and Leyhe, A. (1987). Stomatal activity of the grape berry cv. Riesling, Muller-Thurgau and Ehrenfelser. J. Plant Physiol. 127, 451-460. doi: 10.1016/S0176-1617(87)80253-5

Blatt, M. R. (2000). Cellular signalling and volume control in stomatal movements of plants. Annu. Rev. Cell Dev. Biol. 16, 221-241. doi: 10.1146/annurev.cellbio. 16.1.221

Bondada, B. R., Matthews, M. A., and Shackel, K. A. (2005). Functional xylem in the post-veraison grape berry. J. Exp. Bot. 56, 2949-2957. doi: 10.1093/jxb/eri291

Botella, M. A., Martinez, V., Pardines, J., and Cerda, A. (1997). Salinity induced potassium deficiency in maize plants. J. Plant Physiol. 150, 200-205. doi: 10.1016/S0176-1617(97)80203-9

Botella, M. Á, Arévalo, L., Mestre, T. C., Rubio, F., García-Sánchez, F., Rivero, R. M., et al. (2017). Potassium fertilization enhances pepper fruit quality. J. Plant Nutr. 40, 145-155. doi: 10.1080/01904167.2016.1201501

Boulton, R. (1980). The general relationship between potassium, sodium, $\mathrm{pH}$ in grape juice and wine. Am. J. Enol. Vitic. 31, 182-186.

Breia, R., Vieira, S., da Silva, J. M., Gerós, H., and Cunha, A. (2013). Mapping grape berry photosynthesis by chlorophyll fluorescence imaging: the effect of saturating pulse intensity in different tissues. Photochem. Photobiol. 89, 579-585. doi: 10.1111/php.12046

Burg, M. B., and Ferraris, J. D. (2008). Intracellular organic osmolytes: function and regulation. J. Biol. Chem. 283, 7309-7313. doi: 10.1074/jbc.R700042200

Byrt, C. S., Zhao, M., Kourghi, M., Bose, J., Hendersen, S. W., Qiu, J., et al. (2016). Non-selective cation channel activity of aquaporin AtPIP2;1 regulated by $\mathrm{Ca}^{2+}$ and pH. Plant Cell Environ. 40, 802-815. doi: 10.1111/pce. 12832

Cakmak, I. (2005). The role of potassium in alleviating detrimental effects of abiotic stresses in plants. J. Plant Nutr. Soil Sci. 168, 521-530. doi: 10.1002/jpln. 200420485

Cakmak, I., Hengeler, C., and Marschner, H. (1994). Partitioning of shoot and root dry matter and carbohydrates in bean plants suffering from phosphorus, potassium and magnesium deficiency. J. Exp. Bot. 45, 1245-1250. doi: 10.1093/ jxb/45.9.1245

Caravia, L., Collins, C., and Tyerman, S. D. (2015). Electrical impedance of Shiraz berries correlates with decreasing cell vitality during ripening. Aust. J. Grape Wine Res. 21, 430-438. doi: 10.1111/ajgw.12157

Chen, G., Feng, H., Hu, Q., Qu, H., Chen, A., Yu, L., et al. (2015). Improving rice tolerance to potassium deficiency by enhancing OsHAK16p:WOX11controlled root development. Plant Biotechnol. J. 13, 833-848. doi: 10.1111/pbi. 12320

Chérel, I., Lefoulon, C., Boeglin, M., and Sentenac, H. (2014). Molecular mechanisms involved in plant adaptation to low $\mathrm{K}^{+}$availability. J. Exp. Bot. 65, 833-848. doi: 10.1093/jxb/ert402

Choat, B., Gambetta, G. A., Shackel, K. A., and Matthews, M. A. (2009). Vascular function in grape berries across development and its relevance to apparent hydraulic isolation. Plant Physiol. 151, 1677-1687. doi: 10.1104/pp.109.143172

Clarke, S. J., Hardie, W. J., and Rogiers, S. Y. (2010). Changes in the susceptibility of grape berries to splitting are related to impaired osmotic water uptake associated with losses in cell vitality. Aust. J. Grape Wine Res. 16, 469-476. doi: 10.1111/j.1755-0238.2010.00108.x

Clarke, S. J., Lamont, K. J., Pan, H. Y., Barry, L., Hall, A., and Rogiers, S. Y. (2015). Root-zone temperature regulates root growth, nutrient acquisition and shoot growth dynamics in grapevines. Aust. J. Grape Wine Res. 21, 479-489. doi: 10.1111/ajgw.12160

Conde, B. C., Agasse, A., Glissant, D., Tavares, R. M., Geros, H., and Delrot, S. (2006). Pathways of glucose regulation of monosaccharide transport in grape cells. Plant Physiol. 141, 1563-1577. doi: 10.1104/pp.106.080804

Conde, C., Silva, P., Fontes, N., Dias, A. C., Tavares, R. M., Sousa, M. J., et al. (2007). Biochemical changes throughout grape berry development and fruit and wine quality. Food 1, 1-22. doi: 10.1186/s12864-016-2660-z

Conradie, W. J. (1981). Seasonal uptake of nutrients by Chenin blanc in sand culture: II. Phosphorus, potassium, calcium and magnesium. S. Afr. J. Enol. Vitic. 2, 7-13.

Coombe, B., and Hale, C. (1973). The hormone content of ripening grape berries and the effects of growth substance treatments. Plant Physiol. 51, 629-634. doi: 10.1104/pp.51.4.629

Coombe, B. G. (1992). Research on development and ripening of grape berry. Am. J. Enol. Vitic. 43, 101-110.
Coombe, B. G., and Iland, P. G. (2004). “Grape berry development and winegrape quality," in Viticulture: Resources, eds P. R. Dry and B. G. Coombe (Adelaide, SA: Winetitles), 210-225.

Coombe, B. G., and McCarthy, M. G. (2000). Dynamics of grape berry growth and physiology of ripening. Aust. J. Grape Wine Res. 6, 131-135. doi: 10.1111/j.17550238.2000.tb00171.x

Creasy, G. L., Price, S. F., and Lombard, P. B. (1993). Evidence for xylem discontinuity in Pinot Noir and Merlot: dye uptake and mineral composition during berry maturation. Am. J. Enol. Vitic. 44, 187-192.

Cuéllar, T., Azeem, F., Andrianteranagna, M., Pascaud, F., Verdeil, J. L., Sentenac, H., et al. (2013). Potassium transport in developing fleshy fruits: the grapevine inward $\mathrm{K}^{+}$channel VvK1.2 is activated by CIPK-CBL complexes and induced in ripening berry flesh cells. Plant J. 73, 1006-1018. doi: 10.1111/tpj. 12092

Cuéllar, T., Pascaud, F., Verdeil, J. L., Torregrosa, L., Adam-Blondon, A. F., Thibaud, J. B., et al. (2010). A grapevine Shaker inward $\mathrm{K}^{+}$channel activated by the calcineurin B-like calcium sensor 1-protein kinase CIPK23 network is expressed in grape berries under drought stress conditions. Plant J. 61, 58-69. doi: 10.1111/j.1365-313X.2009.04029.x

Dai, Z. W., Ollat, N., Gomès, E., Decroocq, S., Tandonnet, J. P., Bordenave, L., et al. (2011). Ecophysiological, genetic, and molecular causes of variation in grape berry weight and composition: a review. Am. J. Enol. Vitic. 62, 413-425. doi: 10.5344/ajev.2011.10116

Dai, Z. W., Vivin, P., Barrieu, F., Ollat, N., and Delrot, S. (2010). Physiological and modelling approaches to understand water and carbon fluxes during grape berry growth and quality development: a review. Aust. J. Grape Wine Res. 16, 70-85. doi: 10.1111/j.1755-0238.2009.00071.x

Daudet, F. A., Lacointe, A., Gaudillère, J. P., and Cruiziat, P. (2002). Generalized Münch coupling between sugar and water fluxes for modelling carbon allocation as affected by water status. J. Theor. Biol. 214, 481-498. doi: 10.1006/ jtbi.2001.2473

Davies, C., Boss, P. K., Gerós, H., Lecourieux, F., and Delrot, S. (2012). "Source/sink relationships and molecular biology of sugar accumulation in grape berries," in The Biochemistry of the Grape Berry, eds H. Gerós, M. M. Chaves, and S. Delrot (Sharjah: Bentham Science), 44-66. doi: 10.2174/97816080536051120101

Davies, C., and Robinson, S. P. (1996). Sugar accumulation in grape berries. Plant Physiol. 111, 275-283. doi: 10.1104/pp.111.1.275

Davies, C., Shin, R., Liu, W., Thomas, M. R., and Schachtman, D. P. (2006). Transporters expressed during grape berry (Vitis vinifera L.) development are associated with an increase in berry size and berry potassium accumulation. J. Exp. Bot. 57, 3209-3216. doi: 10.1093/jxb/erl091

Deeken, R., Geiger, D., Fromm, J., Koroleva, O., Ache, P., Langenfeld-Heyser, R., et al. (2002). Loss of the AKT2/3 potassium channel affects sugar loading into the phloem of Arabidopsis. Planta 216, 334-344. doi: 10.1007/s00425-0020895- 1

Degaris, K. A., Walker, R. R., Loveys, B. R., and Tyerman, S. D. (2016). Comparative effects of deficit and partial root-zone drying irrigation techniques using moderately saline water on ion partitioning in Shiraz and Grenache grapevines. Aust. J. Grape Wine Res. 22, 296-306. doi: 10.1111/ajgw.12220

DellaPenna, D., and Pogson, B. J. (2006). Vitamin synthesis in plants: tocopherols and carotenoids. Annu. Rev. Plant Biol. 57, 711-738. doi: 10.1146/annurev. arplant.56.032604.144301

Demidchik, V. (2014). Mechanisms and physiological roles of $\mathrm{K}^{+}$efflux from root cells. J. Plant Phys. 171, 696-707. doi: 10.1016/j.jplph.2014.01.015

Dokoozlian, N., and Kliewer, M. W. (1996). Influence of light on grape berry growth and composition varies during fruit development. J. Am. Soc. Hortic. Sci. 121, 869-874.

dos Santos, T. P., Lopes, C. M., Rodrigues, M. L., de Souza, C. R., Ricardo-daSilva, J. M., Maroco, J. P., et al. (2007). Effects of deficit irrigation strategies on cluster microclimate for improving fruit composition of Moscatel field-grown grapevines. Sci. Hortic. 112, 321-330. doi: 10.1016/j.scienta.2007.01.006

Dry, P. R., Loveys, B. R., Mccarthy, M. G., and Stoll, M. (2001). Strategic irrigation management in Australian vineyards. J. Int. Sci. Vigne Vin 35, 129-139. doi: 10.20870/oeno-one.2001.35.3.1699

Düring, H., Lang, A., and Oggioni, F. (1987). Patterns of water flow in Riesling berries in relation to developmental changes in their xylem morphology. Vitis $26,123-131$. 
Ebadi, A., May, P., Sedgley, M., and Coombe, B. G. (1995). Effect of low temperature near flowering time on ovule development and pollen tube growth in the grapevine (Vitis vinifera L.), cvs Chardonnay and Shiraz. Aust. J. Grape Wine Res. 1, 11-18. doi: 10.1111/j.1755-0238.1995.tb00072.x

Eifert, A., and Eifert, J. (1976). Relationships between potassium supply, yield of grapes, and frost resistance in vines. Potash Rev. 10, 1-6.

Elumalai, R. P., Nagpal, P., and Reed, J. W. (2002). A mutation in the Arabidopsis KT2/KUP2 potassium transporter gene affects shoot cell expansion. Plant Cell 141, 119-131. doi: 10.1105/tpc.010322

Epron, D., Cabral, O. M. R., Laclau, J. P., Dannoura, M., Packer, A. P., Plain, C., et al. (2016). In situ ${ }^{13} \mathrm{CO}_{2}$ pulse labelling of field-grown eucalypt trees revealed the effects of potassium nutrition and throughfall exclusion on phloem transport of photosynthetic carbon. Tree Physiol. 36, 6-21. doi: 10.1093/ treephys/tpv090

Krieger-Liszkay, A. (2005). Singlet oxygen production in photosynthesis. J. Exp. Bot. 56, 337-346. doi: 10.1093/jxb/erh237

Etchebarne, F., Ojeda, H., and Deloire, A. (2009). "Grape berry mineral composition in relation to vine water status and leaf area/fruit ratio," in Grapevine Molecular Physiology and Biotechnology, 2nd Edn, ed. K. A. Roubelakis-Angelakis (Amsterdam: Springer), 53-72. doi: 10.1007/978-90481-2305-6_3

Fan, L. M., Wang, Y. F., Hong, W., and Wu, W. H. (2001). In vitro Arabidopsis pollen germination and characterization of the inward potassium currents in Arabidopsis pollen grain protoplasts. J. Exp. Bot. 52, 1603-1614. doi: 10.1093/ jexbot/52.361.1603

Fennel, A. (2004). "Freezing tolerance and injury in grapevines," in Adaptations and Responses of Woody Plants to Environmental Stresses, ed. R. Arora (Binghamton, NY: Food Products Press), 201-235.

Fillion, L., Ageorges, A., Picaud, S., Coutos-Thevenot, P., Lemoine, R., Romieu, C., et al. (1999). Cloning and expression of a hexose transporter gene expressed during the ripening of grape berry. Plant Physiol. 120, 1083-1093. doi: 10.1104/ pp.120.4.1083

Findlay, N., Oliver, K. J., Nii, N., and Coombe, B. G. (1987). Solute accumulation by grape pericarp cells. IV. Perfusion of pericarp apoplast via the pedicel and evidence for xylem malfunction in ripening berries. J. Exp. Bot. 38, 668-679. doi: $10.1093 / \mathrm{jxb} / 38.4 .668$

Fontes, N., Côrte-Real, M., and Gerós, H. (2011). New observations on the integrity, structure, and physiology of flesh cells from fully ripened grape berry. Am. J. Enol. Vitic. 62, 279-284. doi: 10.5344/ajev.2011. 10126

Fouquet, R., Leon, C., Ollat, N., and Barrieu, F. (2008). Identification of grapevine aquaporins and expression analysis in developing berries. Plant Cell Rep. 27, 1541-1550. doi: 10.1007/s00299-008-0566-1

Foyer, C. H., and Noctor, G. (2003). Redox sensing and signalling associated with reactive oxygen in chloroplasts, peroxisomes and mitochondria. Physiol. Plant 119, 355-364. doi: 10.1034/j.1399-3054.2003.00223.x

Franklin-Tong, V. E. (1999). Signaling and the modulation of pollen tube growth. Plant Cell 11, 727-738. doi: 10.1105/tpc.11.4.727

Freeman, B. M., and Kliewer, W. M. (1983). Effect of irrigation, crop level and potassium fertilization on Carignane vines. II. Grape and wine quality. Am. J. Enol. Vitic. 34, 197-207.

Fuentes, S., Sullivan, W., Tilbrook, J., and Tyerman, S. D. (2010). A novel analysis of grapevine berry tissue demonstrates a variety-dependent correlation between tissue vitality and shrivel. Aust. J. Grape Wine Res. 13, 66-71. doi: 10.1111/j. 1755-0238.2010.00095.x

Gadjev, I., Stone, J. M., and Gechev, T. S. (2008). Programmed cell death in plants: new insights into redox regulation and the role of hydrogen peroxide. Int. Rev. Cell Mol. Biol. 270, 87-144. doi: 10.1016/S1937-6448(08) 01403-2

Gajdanowicz, P., Michard, E., Sandmann, M., Rocha, M., Correa, L. G. G., RamirezAguilar, S. J., et al. (2011). Potassium $\left(\mathrm{K}^{+}\right)$gradients serve as a mobile energy source in plant vascular tissues. Proc. Natl. Acad. Sci. U.S.A. 108, 864-869. doi: $10.1073 /$ pnas. 1009777108

Galinski, E. A. (1995). Osmoadaptation in bacteria. Adv. Microb. Physiol. 37, 272-328. doi: 10.1016/S0065-2911(08)60148-4

Ghan, R., Petereit, J., Tillett, R. L., Schlauch, K. A., Toubiana, D., Fait, A., et al. (2017). The common transcriptional subnetworks of the grape berry skin in the late stages of ripening. BMC Plant Biol. 17:94. doi: 10.1186/s12870-017-1043-1
Gierth, M., and Mäser, P. (2007). Potassium transporters in plants- involvement in $\mathrm{K}^{+}$acquisition, redistribution and homeostasis. FEBS Lett. 581, 2348-2356. doi: 10.1016/j.febslet.2007.03.035

Gillaspy, G., Ben-David, H., and Gruissem, W. (1993). Fruits: a developmental perspective. Plant Cell 5, 1439-1451. doi: 10.1105/tpc.5.10. 1439

Gong, H., Blackmore, D. H., and Walker, R. R. (2010). Organic and inorganic anions in Shiraz and Chardonnay grape berries and wine as affected by rootstock under saline conditions. Aust. J. Grape Wine Res. 16, 227-236. doi: 10.1111/j.1755-0238.2009.00070.x

Greenspan, M. D., Schultz, H. R., and Matthews, M. A. (1996). Field evaluation of water transport in grape berries during water deficit. Physiol. Plant. 97, 55-62. doi: 10.1111/j.1399-3054.1996.tb00478.x

Greenspan, M. D., Shackel, K. D., and Matthews, M. A. (1994). Developmental changes in the diurnal water budget of grape berry exposed to water deficits. Plant Cell Environ. 17, 811-820. doi: 10.1111/j.1365-3040.1994.tb00175.x

Greer, D. H., and Rogiers, S. Y. (2009). Water flux of Vitis vinifera L. cv. Shiraz bunches throughout development and in relation to late season weight loss. Am. J. Enol. Vitic. 60, 155-163.

Haddad, R., and Kamangar, A. (2016). The ameliorative effect of silicon and potassium on drought stressed grape (Vitis vinifera L.) leaves. Iran. J. Genet. Plant Breed. 4, 46-56.

Hafke, J. B., van Amerongen, J.-K., Kelling, F., Furch, A. C. U., Gaupels, F., and van Bel, A. J. E. (2005). Thermodynamic battle for photosynthate acquisition between sieve tubes and adjoining parenchyma in transport phloem. Plant Physiol. 138, 1527-1537. doi: 10.1104/pp.104.058511

Hale, C. R. (1977). Relation between potassium and the malate and tartare contents in grape berries. Vitis 16, 9-19.

Hanana, M., Cagnac, O., Yamaguchi, T., Hamdi, S., Ghorbel, A., and Blumwald, E. (2007). A grape berry (Vitis vinifera L.) cation/proton antiporter is associated with berry ripening. Plant Cell Physiol. 48, 804-811. doi: 10.1093/pcp/ pcm048

Hannan, J. M. (2011). Potassium-Magnesium Antagonism in High Magnesium Vineyard Soils. Master's thesis, Iowa State University, Ames IA.

Hardie, W. J., O’Brien, T. P., and Jaudzems, V. G. (1996). Morphology, anatomy and development of the pericarp after anthesis in grape, Vitis vinifera L. Aust. J. Grape Wine Res. 2, 97-142. doi: 10.1111/j.1755-0238.1996.tb00101.x

Harris, J. M., Kriedemann, P. E., and Possingham, J. V. (1968). Anatomical aspects of grape berry development. Vitis 7, 106-119.

Hayes, M. A., Davies, C., and Dry, I. B. (2007). Isolation, functional characterization, and expression analysis of grapevine (Vitis vinifera L.) hexose transporters: differential roles in sink and source tissues. J. Exp. Bot. 58, 1985-1997. doi: 10.1093/jxb/erm061

Hepner, Y., and Bravdo, B. (1985). Effect of crop level and drip irrigation scheduling on the potassium status of Cabernet Sauvignon and Carignane vines and its influence on must and wine composition and quality. Am. J. Enol. Vitic. $36,140-147$.

Hocking, B., Tyerman, S. D., Burton, R. A., and Gilliham, M. (2016). Fruit calcium: transport and physiology. Front. Plant Sci. 7:569. doi: 10.3389/fpls.2016.00569

Hrazdina, G., Parsons, G. F., and Mattick, L. R. (1984). Physiological and biochemical events during development and ripening of grape berries. Am. J. Enol. Vitic. 35, 220-227. doi: 10.1093/jxb/erq434

Hsiao, T. C., and Läuchli, A. (1986). "Role of potassium in plant-water relations," in Advances in Plant Nutrition, Vol. 2, eds B. Tinker and A. Läuchli (New York, NY: Praeger Publishers), 281-312.

Hu, W., Lv, X., Yang, J., Chen, B., Zhao, W., Meng, Y., et al. (2016). Effects of potassium deficiency on antioxidant metabolism related to leaf senescence in cotton (Gossypium hirsutum L.). Field Crop Res. 191, 139-149. doi: 10.1016/j. fcr.2016.02.025

Hu, Y. C., and Schmidhalter, U. (2005). Drought and salinity: a comparison of their effects on mineral nutrition of plants. J. Plant Nutr. Soil Sci. 168, 541-549. doi: $10.1002 /$ jpln.200420516

Huang, X., and Huang, H. (2001). Early post-veraison growth in grapes: evidence for a two-step mode of berry enlargement. Aust. J. Grape Wine Res. 7, 132-136. doi: 10.1111/j.1755-0238.2001.tb00200.x

Iland, P. G., and Coombe, B. G. (1988). Malate, tartrate, potassium and sodium in flesh and skin of Shiraz grapes during ripening: concentration and compartmentation. Am. J. Enol. Vitic. 39, 71-76. 
Jaillon, O., Aury, J.-M., Noel, B., Policriti, A., Clepet, C., Casagrande, A., et al. (2007). The grapevine genome sequence suggests ancestral hexaploidization in major angiosperm phyla. Nature 449, 463-467. doi: 10.1038/nature06148

Jiang, M., and Zhang, J. (2001). Effect of abscisic acid on active oxygen species, antioxidative defence system and oxidative damage in leaves of maize seedlings. Plant Cell Physiol. 42, 1265-1273. doi: 10.1093/pcp/pce12

Kanai, S., Moghaieb, R. E., El-Shemy, H. A., Panigrahi, R., Mohapatra, P. K., Ito, J., et al. (2011). Potassium deficiency affects water status and photosynthetic rate of the vegetative sink in green house tomato prior to its effects on source activity. Plant Sci. 180, 368-374. doi: 10.1016/j.plantsci.2010. 10.011

Keller, M. (2015). The Science of Grapevines, 2nd Edn. London: Academic Press.

Keller, M., and Shrestha, P. M. (2014). Solute accumulation differs in the vacuoles and apoplast of ripening grape berries. Planta 239, 633-642. doi: 10.1007/ s00425-013-2004-z

Keller, M., Smith, J. P., and Bondada, B. R. (2006). Ripening grape berries remain hydraulically connected to the shoot. J. Exp. Bot. 57, 2577-2587. doi: 10.1093/ jxb/erl020

Keller, M., Zhang, Y., Shrestha, P. M., Biondi, M., and Bondada, B. R. (2015). Sugar demand of ripening grape berries leads to recycling of surplus phloem water via the xylem. Plant Cell Environ. 38, 1048-1059. doi: 10.1111/pce. 12465

Kim, E. J., Kwak, J. M., Uozumi, N., and Schroeder, J. I. (1998). AtKUP1: an Arabidopsis gene encoding high-affinity potassium transport activity. Plant Cell 10, 51-62. doi: 10.1105/tpc.10.1.51

Kim, M. J., Ciani, S., and Schachtman, D. P. (2010). A peroxidase contributes to ROS production during Arabidopsis root response to potassium deficiency. Mol. Plant 3, 420-427. doi: 10.1093/mp/ssp121

Klein, I., Strime, M., Fanberstein, L., and Mani, Y. (2000). Irrigation and fertigation effects on phosphorus and potassium nutrition of wine grapes. Vitis 39, 55-62.

Kodur, S. (2011). Effects of juice $\mathrm{pH}$ and potassium on juice and wine quality, and regulation of potassium in grapevines through rootstocks (Vitis): a short review. Vitis 50, 1-6.

Kodur, S., Tisdall, J. M., Tang, C., and Walker, R. R. (2010). Accumulation of potassium in grapevine rootstocks (Vitis) grafted to 'Shiraz' as affected by growth, root-traits and transpiration. Vitis 49, 7-13.

Kodur, S., Tisdall, J. M., Tang, C., and Walker, R. R. (2011). Uptake, transport, accumulation and retranslocation of potassium in grapevine rootstocks (Vitis). Vitis 50, 145-149.

Köhler, B., Hills, A., and Blatt, M. R. (2003). Control of guard cell ion channels by hydrogen peroxide and abscisic acid indicates their action through alternate signalling pathways. Plant Physiol. 131, 385-388. doi: 10.1104/pp. 016014

Krasnow, M., Matthews, M., and Shackel, K. (2008). Evidence for substantial maintenance of membrane integrity and cell viability in normally developing grape (Vitis vinifera L.) berries throughout development. J. Exp. Bot. 59, 849-859. doi: 10.1093/jxb/erm372

Lacombe, B., Pilot, G., Michard, E., Gaymard, F., Sentenac, H., and Thibaud, J.-B. (2000). A shaker-like $\mathrm{K}^{+}$channel with weak rectification is expressed in both source and sink phloem tissues of Arabidopsis. Plant Cell 12, 837-851.

Lang, A. (1983). Turgor-related translocation. Plant Cell Environ. 6, 683-689. doi: 10.1111/1365-3040.ep11589312

Lang, A. (1990). Xylem, phloem and transpiration flows in developing apple fruits. J. Exp. Bot. 41, 645-651. doi: 10.1093/jxb/41.6.645

Lang, A., and Düring, H. (1991). Partitioning control by water potential gradient: evidence for compartmentation breakdown in grape berries. J. Exp. Bot. 42, 1117-1122. doi: 10.1093/jxb/42.9.1117

Lang, A., and Thorpe, M. R. (1986). Water potential, translocation and assimilate partitioning. J. Exp. Bot. 37, 495-503. doi: 10.1093/jxb/37.4.495

Lang, A., and Thorpe, M. R. (1989). Xylem, phloem and transpiration flows in a grape: application of a technique for measuring the volume of attached fruits to high resolution using Archimedes' principle. J. Exp. Bot. 40, 1069-1078. doi: $10.1093 / \mathrm{jxb} / 40.10 .1069$

Läuchli, A., and Epstein, E. (1970). Transport of potassium and rubidium in plant roots: the significance of calcium. Plant Physiol. 45, 639-641. doi: 10.1104/pp. 45.5.639

Lavee, S., and Nir, G. (1986). "Grape," in CRC Handbook of Fruit Set and Development, ed. S. P. Monselise (Boca Raton, FL: CRC Press), 167-191.
Lester, G. E., Jifon, J. L., and Makus, D. J. (2010). Impact of potassium nutrition on postharvest fruit quality: melon (Cucumis melo L) case study. Plant Soil 335, 117-131. doi: 10.1007/s11104-009-0227-3

Liesche, J. (2016). How regulation of phloem transport could link potassium fertilization to increased growth. Tree Physiol. 36, 1-5. doi: 10.1093/treephys/ tpv120

Ma, T. L., Wu, W. H., and Wang, Y. (2012). Transcriptome analysis of rice root responses to potassium deficiency. BMC Plant Biol. 12:161. doi: 10.1186/14712229-12-161

Manning, K., Davies, C., Bowen, H. C., and White, P. J. (2001). Functional characterization of two ripening-related sucrose transporters from grape berries. Ann. Bot. 87, 125-129. doi: 10.1006/anbo.2000.1316

Mantell, A., Goldschmidt, E. E., and Monselise, S. P. (1980). Turnover of tritiated water in calamondin plants (Citrus madurensis). J. Am. Soc. Hortic. Sci. 105, 741-744.

Marcelis, L. F. M. (1996). Sink strength as a determinant of dry matter partitioning in the whole plant. J. Exp. Bot. 47, 1281-1291. doi: 10.1093/jxb/47.Special_Issue. 1281

Marschner, H. (1995). Mineral Nutrition of Higher Plants, Second Edn. London: Academic Press.

Martins, V., Cunha, A., Gerós, H., Hanana, M., and Blumwald, E. (2012). "Mineral compounds in grape berry," in The Biochemistry of the Grape Berry, eds H. Gerós, M. M. Chaves, and S. Delrot (Sharjah: Bentham Science), 23-43. doi: 10.2174/97816080536051120101

Matthews, M. A., and Shackel, K. A. (2005). "Growth and water transport in fleshy fruit," in Vascular Transport in Plants, eds N. M. Holbrook and M. A. Zwieniecki (Burlington, CA: Academic Press), 189-197.

Mattick, L. R., Shaulis, N. J., and Moyer, J. C. (1972). The effect of potassium fertilisation on the acid content of 'Concord' grape juice. Am. J. Enol. Vitic. 23, 26-30.

Matus, J. T., Loyola, R., Vega, A., Peña-Neira, A., Bordeu, E., Arce-Johnson, P., et al. (2009). Post-veraison sunlight exposure induces MYB-mediated transcriptional regulation of anthocyanin and flavonol synthesis in berry skins of Vitis vinifera. J. Exp. Bot. 60, 853-867. doi: 10.1093/jxb/ern336

May, P. (2004). Flowering and Fruitset in Grapevines. Adelaide, SA: Lythrum Press. Melotto, M., Underwood, W., Koczan, J., Nomura, K., and He, S. Y. (2006). Plant stomata function in innate immunity against bacterial invasion. Cell 126, 969-980. doi: 10.1016/j.cell.2006.06.054

Meneghetti, S., Gardiman, M., and Calò, A. (2006). Flower biology of grapevine. A review. Adv. Hortic. Sci. 20, 317-325. doi: 10.1016/j.gde.2008.11.005

Mengel, K., and Kirkby, E. A. (1987). Principles of Plant Nutrition. Bern: International Potash Institute.

Minchin, P. E. H., and Thorpe, M. R. (1987). Measurement of unloading and reloading of photoassimilate within the stem of bean. J. Exp. Bot. 38, 211-220. doi: $10.1093 / \mathrm{jxb} / 38.2 .211$

Mitra, G. N. (2015). "Potassium (K) uptake," in Regulation of Nutrient Uptake by Plants: A Biochemical and Molecular Approach, ed. G. N. Mitra (New Delhi: Springer), 25-42. doi: 10.1007/978-81-322-2334-4-4

Mouline, K., Véry, A. A., Gaymard, F., Boucherez, J., Pilot, G., Devic, M., et al. (2002). Pollen tube development and competitive ability are impaired by disruption of a Shaker $\mathrm{K}^{+}$channel in Arabidopsis. Genes Dev. 16, 339-350. doi: $10.1101 / \operatorname{gad} .213902$

Mpelasoka, B. S., Schachtman, D. P., Treeby, M. T., and Thomas, M. R. (2003). A review of potassium nutrition in grapevines with special emphasis on berry accumulation. Aust. J. Grape Wine Res. 9, 154-168. doi: 10.1111/j.1755-0238. 2003.tb00265.x

Mullineaux, P. M., and Baker, N. R. (2010). Oxidative stress: antagonistic signaling for acclimation or cell death? Plant Physiol. 154, 521-525. doi: 10.1104/pp.110. 161406

Mullins, M. G., Bouquet, A., and Williams, L. E. (1992). Biology of the Grapevine. Cambridge: Cambridge University Press.

Nava, G., Roque-Dechen, A., and Ribeiro-Nachtiga, G. (2008). Nitrogen and potassium fertilization affect apple fruit quality in southern Brazil. Comm. Soil Sci. Plant Anal. 39, 96-107. doi: 10.1080/00103620701759038

Nguyen, T. H., Huang, S., Meynard, D., Chaine, C., Michel, R., Roelfsema, M. R. G., et al. (2017). A dual role for the OsK5. 2 ion channel in stomatal movements and $\mathrm{K}^{+}$loading into xylem sap. Plant Physiol. 174, 2409-2418. doi: 10.1104/pp.17. 00691 
Nicholas, P. R., Magarey, P. A., and Wachtel, M. F. (1994). Diseases and Pests (Grape Production Series No. 1). Adelaide, SA: Winetitles.

O’Brien, J. A., Daudi, A., Butt, V. S., and Bolwell, G. P. (2012). Reactive oxygen species and their role in plant defence and cell wall metabolism. Planta 236, 765-779. doi: 10.1007/s00425-012-1696-9

Ollat, N., and Gaudillère, J. P. (1996). Investigation of assimilate import mechanisms in berries of Vitis vinifera var. 'Cabernet Sauvignon'. Acta Hortic. 427, 141-149. doi: 10.17660/ActaHortic.1996.427.17

Ollat, N., and Gaudillère, J. P. (2000). Carbon balance in developing grapevine berries. Acta Hortic. 526, 345-350. doi: 10.17660/ActaHortic.2000.526.37

Osakabe, Y., Arinaga, N., Umezawa, T., Katsura, S., Nagamachi, K., and Tanaka, H. (2013). Osmotic stress responses and plant growth controlled by potassium transporters in Arabidopsis. Plant Cell 25, 609-624. doi: 10.1105/tpc.112.105700

Palliotti, A., and Cartechini, A. (2001). Developmental changes in gas exchange activity in flowers, berries, and tendrils of field-grown Cabernet Sauvignon. Am. J. Enol. Vitic. 52, 317-323.

Palumbo, M. C., Zenoni, S., Fasoli, M., Massonnet, M., Farina, L., Castiglione, F., et al. (2014). Integrated network analysis identifies fight-club nodes as a class of hubs encompassing key putative switch genes that induce major transcriptome reprogramming during grapevine development. Plant Cell 26, 4617-4635. doi: $10.1105 /$ tpc. 114.133710

Patakas, A., Nikolaou, N., Zioziou, E., Radoglou, K., and Noitsakis, B. (2002). The role of organic solute and ion accumulation in osmotic adjustment in droughtstressed grapevines. Plant Sci. 163, 361-367. doi: 10.1016/S0168-9452(02) 00140-1

Patrick, J. W. (1997). Phloem unloading: sieve element unloading and post-sieve element transport. Annu. Rev. Plant Physiol. Plant Mol. Biol. 48, 191-222. doi: 10.1146/annurev.arplant.48.1.191

Patrick, J. W., and Offler, C. E. (1996). Post-sieve element transport of photoassimilates in sink regions. J. Exp. Bot. 28, 736-743. doi: 10.1093/jxb/47. Special_Issue. 1165

Perrenoud, S. (1990). Potassium and Plant Health, 2nd Edn. Bern: International Potash Institute.

Philippar, K., Buchsenschutz, K., Abshagen, M., Fuchs, I., Geiger, D., Lacombe, B., et al. (2003). The $\mathrm{K}^{+}$channel KZM1 mediates potassium uptake into the phloem and guard cells of the C4 grass Zea mays. J. Biol. Chem. 278, 16973-16981. doi: 10.1074/jbc.M212720200

Picaud, S., Becq, F., Dédaldéchamp, F., Ageorges, A., and Delrot, S. (2003). Cloning and expression of two plasma membrane aquaporins expressed during the ripening of grape berry. Funct. Plant Biol. 30, 621-630. doi: 10.1071/FP02116

Pilati, S., Brazzale, D., Guella, G., Milli, A., Ruberti, C., Biasioli, F., et al. (2014). The onset of grapevine berry ripening is characterized by ROS accumulation and lipoxygenase-mediated membrane peroxidation in the skin. BMC Plant Biol. 14:87. doi: 10.1186/1471-2229-14-87

Pilati, S., Perazzolli, M., Malossini, A., Cestaro, A., Dematte, L., Fontana, P., et al. (2007). Genome-wide transcriptional analysis of grapevine berry ripening reveals a set of genes similarly modulated during three seasons and the occurrence of an oxidative burst at veraison. BMC Genomics 8:428. doi: 10.1186/ 1471-2164-8-428

Possner, D. R. E., and Kliewer, W. M. (1985). The localisation of acids, sugars, potassium and calcium in developing grape berries. Vitis 24, 229-240.

Pradubsuk, S., and Davenport, J. R. (2010). Seasonal uptake and partitioning of macronutrients in mature 'Concord' grape. J. Am. Soc. Hortic. Sci. 135, 474-483.

Pratelli, R., Lacombe, B., Torregrosa, L., Gaymard, F., Romieu, C., Thibaud, J., et al. (2002). A grapevine gene encoding a guard cell $\mathrm{K}^{+}$channel displays developmental regulation in the grapevine berry. Plant Physiol. 128, 564-577. doi: 10.1104/pp.010529

Pratt, C. (1971). Reproductive anatomy in cultivated grapes- a review. Am. J. Enol. Vitic. 22, 92-109.

Ramos, M. C., and Romero, M. P. (2017). Potassium uptake and redistribution in Cabernet Sauvignon and Syrah grape tissues and its relationship with grape quality parameters. J. Sci. Food Agric. 97, 3268-3277. doi: 10.1002/jsfa. 8175

Rehman, S., Rha, E. S., Ashraf, M., Lee, K. J., Yun, S. J., Kwak, Y. G., et al. (2004). Does barley (Hordeum vulgare L.) pollen swell in fractions of a second? Plant Sci. 167, 137-142. doi: 10.1016/j.plantsci.2004.03.013

Rigas, S., Debrosses, G., Haralampidis, K., Vicente-Agullo, F., Feldmann, K. A., Grabov, A., et al. (2001). TRH1 encodes a potassium transporter required for tip growth in Arabidopsis root hairs. Plant Cell 13, 139-151. doi: 10.1105/tpc. 13.1.139

Robinson, J. B. (1992). "Grapevine nutrition," in Viticulture, Vol. 2, eds B. G. Coombe and P. R. Dry (Adelaide, SA: Winetitles), 178-208.

Roby, G., and Matthews, M. A. (2004). Relative proportions of seed, skin and flesh, in ripe berries from Cabernet Sauvignon grapevines grown in a vineyard either well irrigated or under water deficit. Aust. J. Grape Wine Res. 10, 74-82. doi: 10.1111/j.1755-0238.2004.tb00009.x

Rogiers, S. Y., Greer, D. H., Clarke, S. J., and Sicard, S. M. (2016). Vine and soil determinants of Semillon berry composition. Acta Hortic. 1115, 133-138. doi: 10.17660/ActaHortic.2016.1115.20

Rogiers, S. Y., Greer, D. H., Hatfield, J. M., Orchard, B. A., and Keller, M. (2006a). Mineral sinks within ripening grape berries Vitis vinifera (L). Vitis 45, 115-123.

Rogiers, S. Y., Greer, D. H., Hatfield, J. M., Orchard, B. A., and Keller, M. (2006b). Solute transport into Shiraz berries during development and late-ripening shrinkage. Am. J. Enol. Vitic. 57, 73-80.

Rogiers, S. Y., Hatfield, J. M., Jaudzems, V. G., White, R. G., and Keller, M. (2004). Grape berry $\mathrm{cv}$. Shiraz epicuticular wax and transpiration during ripening and preharvest weight loss. Am. J. Enol. Vitic. 55, 121-127.

Rogiers, S. Y., Keller, M., Holzapfel, B. P., and Virgona, J. M. (2000). Accumulation of potassium and calcium by ripening berries on field vines of Vitis vinifera $(\mathrm{L})$ cv. Shiraz. Aust. J. Grape Wine Res. 6, 240-243. doi: 10.1111/j.1755-0238.2000. tb00184.x

Rogiers, S. Y., Kumar, G. N. M., and Knowles, N. R. (1998). Maturation and ripening of fruit of Amelanchier alnifolia Nutt. are accompanied by increasing oxidative stress. Ann. Bot. 81, 203-211. doi: 10.1006/anbo.1997.0543

Rojas-Lara, B. A., and Morrison, J. C. (1989). Differential effects of shading fruit or foliage on the development and composition of berries. Vitis 28, 199-208.

Ruan, Y. L., Llewellyn, D. J., and Furbank, R. T. (2001). The control of single-celled cotton fiber elongation by developmentally reversible gating of plasmodesmata and coordinated expression of sucrose and $\mathrm{K}^{+}$transporters and expansin. Plant Cell 13, 47-60.

Ruan, Y. L., and Patrick, J. W. (1995). The cellular pathway of postphloem sugar transport in developing tomato fruit. Planta 196, 434-444. doi: 10.1007/ BF00203641

Ruhl, E. H. (1989). Effect of potassium and nitrogen supply on the distribution of minerals and organic acids and the composition of grape juice of Sultana vines. Aust. J. Exp. Agric. 29, 133-137. doi: 10.1071/EA9890133

Sadras, V., and McCarthy, M. G. (2007). Quantifying the dynamics of sugar concentration in berries of Vitis vinifera cv. Shiraz: a novel approach based on allometric analysis. Aust. J. Grape Wine Res. 13, 66-71. doi: 10.1111/j.17550238.2007.tb00236.x

Sakamoto, H., Matsuda, O., and Iba, K. (2008). ITN1, a novel gene encoding an ankyrin-repeat protein that affects the ABA-mediated production of reactive oxygen species and is involved in salt-stress tolerance in Arabidopsis thaliana. Plant J. 56, 411-422. doi: 10.1111/j.1365-313X.2008.03614.x

Sarry, J. E., Sommerer, N., Sauvage, F. X., Bergoin, A., Rossignol, M., Albagnac, G., et al. (2004). Grape berry biochemistry revisited upon proteomic analysis of the mesocarp. Proteomics 4, 201-215. doi: 10.1002/pmic.200300499

Schachtman, D. P. (2000). Molecular insights into the structure and function of $\mathrm{K}^{+}$transport mechanisms. Biochim. Biophys. Acta 1465, 127-139. doi: 10.1016/ S0005-2736(00)00134-6

Scharwies, J. D., and Tyerman, S. D. (2016). Comparison of isohydric and anisohydric Vitis vinifera L. cultivars reveals a fine balance between hydraulic resistances, driving forces and transpiration in ripening berries. Funct. Plant Biol. 44, 324-338. doi: 10.1071/FP16010

Schobert, C., Zhong, W.-J., and Komor, E. (1998). Inorganic ions modulate the path of phloem loading of sucrose in Ricinus communis L. seedlings. Plant Cell Environ. 21, 1047-1054. doi: 10.1046/j.1365-3040.1998.00354.x

Schreiner, R. P., Scagel, C. F., and Baham, J. (2006). Nutrient uptake and distribution in a mature 'Pinot Noir' vineyard. HortScience 41, 336-345.

Serpe, M., and Matthews, M. (2000). Turgor and cell wall yielding in dicot leaf growth in response to changes in relative humidity. Aust. J. Plant Physiol. 27, 142-147. doi: 10.1071/PP00055

Shabala, S. (2009). Salinity and programmed cell death: unravelling mechanisms for ion specific signalling. J. Exp. Bot. 60, 709-712. doi: 10.1093/jxb/erp013

Shabala, S. (2017). Signalling by potassium: another second messenger to add to the list? J. Exp. Bot. 68, 4003-4007. doi: 10.1093/jxb/erx238 
Shabala, S., Bose, J., Fuglsang, A. T., and Pottosin, I. (2016). On a quest for stress tolerance genes: membrane transporters in sensing and adapting to hostile soils. J. Exp. Bot. 67, 1015-1031. doi: 10.1093/jxb/erv465

Shabala, S., and Pottosin, I. (2014). Regulation of potassium transport in plants under hostile conditions: implications for abiotic and biotic stress tolerance. Physiol. Plant. 151, 257-279. doi: 10.1111/ppl.12165

Shabala, S., and Pottosin, I. I. (2010). "Potassium and potassium-permeable channels in plant salt tolerance," in Ion Channels and Plant Stress Responses, eds V. Demidchik and F. Maathuis (Berlin: Springer-Verlag), 87-110. doi: 10.1007/978-3-642-10494-7_5

Shabala, S., and Wilson, S. (2001). Fluctuations in light intensity modulate ion fluxes from grape berry mesocarp: direct evidence from microelectrode ion flux estimations. Aust. J. Grape Wine Res. 7, 137-143. doi: 10.1111/j.1755-0238.2001. tb00201.x

Shannon, P., Markiel, A., Ozier, O., Baliga, N. S., Wang, J. T., Ramage, D., et al. (2003). Cytoscape: a software environment for integrated models of biomolecular interaction networks. Genome Res. 13, 2498-2504. doi: 10.1101/ gr.1239303

Shen, C., Wang, J., Shi, X., Kang, Y., Xie, C., Peng, L., et al. (2017). Transcriptome analysis of differentially expressed genes induced by low and high potassium levels provides insight into fruit sugar metabolism of pear. Front. Plant Sci. 8:938. doi: 10.3389/fpls.2017.00938

Smart, L. B., Moskal, W. A., Cameron, K. D., and Bennett, A. B. (2001). MIP genes are down-regulated under drought stress in Nicotiana glauca. Plant Cell Physiol. 42, 686-693. doi: 10.1093/pcp/pce085

Smart, R. E., Robinson, J. B., Due, G. R., and Brien, C. J. (1985). Canopy microclimate modification for the cultivar Shiraz. II. Effects on must and wine composition. Vitis 24, 119-128.

Smith, J. A. C., and Milburn, J. A. (1980a). Osmoregulation and the control of phloem-sap composition in Ricinus communis L. Planta 148, 28-34. doi: 10.1007/BF00385438

Smith, J. A. C., and Milburn, J. A. (1980b). Phloem turgor and the regulation of sucrose loading in Ricinus communis L. Planta 148, 42-48. doi: 10.1007/ BF00385440

Somers, T. C. (1977). A connection between potassium levels in the harvest and relative quality in Australian red wines. Aust. Wine Brew. Spirit Rev. 24, 32-34.

Song, M., Wang, S., Chai, L., Zhang, S., and Shen, Y. (2017). Characterization of an $\mathrm{ABA}$-induced and $\mathrm{K}^{+}$channel gene FaKAT1 that regulates strawberry fruit ripening. J. Plant Growth Regul. 36, 312-332. doi: 10.1007/s00344-016-9641-y

Song, Z., Guo, S., Zhang, C., Zhang, B., Ma, R., Korir, N. K., et al. (2015). $\mathrm{KT} / \mathrm{HAK} / \mathrm{KUP}$ potassium transporter genes differentially expressed during fruit development, ripening, and postharvest shelf-life of 'Xiahui6' peaches. Acta Physiol. Plant. 37, 1-9. doi: 10.1007/s11738-015-1880-1

Staudt, G. (1982). Pollen germination and pollen tube growth in vivo and the dependence on temperature. Vitis 21, 205-216.

Storey, R. (1987). Potassium localization in the grape berry pericarp by energydispersive X-ray microanalysis. Am. J. Enol. Vitic. 38, 301-309.

Sweetman, C., Deluc, L., Cramer, G., Ford, C., and Soole, K. (2009). Regulation of malate metabolism in grape berry and other developing fruits. Phytochemistry 70, 1329-1344. doi: 10.1016/j.phytochem.2009.08.006

Sweetman, C., Wong, D. C., Ford, C. M., and Drew, D. P. (2012). Transcriptome analysis at four developmental stages of grape berry (Vitis vinifera cv. Shiraz) provides insights into regulated and coordinated gene expression. BMC Genomics 13:691. doi: 10.1186/1471-2164-13-691

Taylor, P. L., and Hepler, K. (1997). Pollen germination and tube growth. Annu. Rev. Plant Physiol. Plant Mol. Biol. 48, 461-491. doi: 10.1146/annurev.arplant. 48.1.461

Tazawa, M., Sutou, E., and Shibasaka, M. (2001). Onion root water transport sensitive to water channel and $\mathrm{K}^{+}$channel inhibitors. Plant Cell Physiol. 42, 28-36. doi: 10.1093/pcp/pce004

Terrier, N., Glissant, D., Grimplet, J., Barrieu, F., Abbal, P., Couture, C., et al. (2005). Isogene specific oligo arrays reveal multifaceted changes in gene expression during grape berry (Vitis vinifera L.) development. Planta 222, 832-847. doi: 10.1007/s00425-005-0017-y

Terrier, N., Sauvage, F. X., Ageorges, A., and Romieu, C. (2001). Changes in acidity and in proton transport at the tonoplast of grape berries during development. Planta 213, 20-28. doi: 10.1007/s004250000472
Tester, M. (1990). Plant ion channels: whole-cell and single-channel studies. New Phytol. 114, 305-340. doi: 10.1111/j.1469-8137.1990.tb00403.x

Thomas, T. R., Matthews, M. A., and Shackel, K. A. (2006). Direct in situ measurement of cell turgor in grape (Vitis vinifera L.) berries during development and in response to plant water deficits. Plant Cell Environ. 29, 993-1001. doi: 10.1111/j.1365-3040.2006.01496.x

Thomashow, M. F. (1999). Plant cold acclimation: freezing tolerance genes and regulatory mechanisms. Annu. Rev. Plant Biol. 50, 571-599. doi: 10.1146/ annurev.arplant.50.1.571

Thompson, M., and Holbrook, N. (2003). Scaling phloem transport: water potential equilibrium and osmoregulatory flow. Plant Cell Environ. 26, 1561-1577. doi: 10.1046/j.1365-3040.2003.01080.x

Thompson, M. V., and Zwieniecki, M. A. (2005). "The role of potassium in long distance transport in plants," in Vascular Transport in Plants, eds N. M. Holbrook and M. A. Zwieniecki (Burlington, CA: Academic Press), 221-240.

Tilbrook, J., and Tyerman, S. D. (2008). Cell death in grape berries: varietal differences linked to xylem pressure and berry weight loss. Funct. Plant Biol. 35, 173-184. doi: 10.1071/FP07278

Tilbrook, J., and Tyerman, S. D. (2009). Hydraulic connection of grape berries to the vine: varietal differences in water conductance into and out of berries, and potential for backflow. Funct. Plant Biol. 36, 541-550. doi: 10.1071/FP09019

Tyerman, S. D., Chaves, M. M., and Barrieu, F. (2012). "Water relations of the grape berry and aquaporins," in The Biochemistry of the Grape Berry, eds H. Gerós, M. M. Chaves, and S. Delrot (Sharjah: Bentham Science), 3-22. doi: 10.2174/97816080536051120101

Tyerman, S. D., Tilbrook, J., Pardo, C., Kotula, L., Sullivan, W., and Steudle, E. (2004). Direct measurement of hydraulic properties in developing berries of Vitis vinifera L. cv Shiraz and Chardonnay. Aust. J. Grape Wine Res. 10, 170-181. doi: 10.1111/j.1755-0238.2004.tb00020.x

Tyree, M. T., and Fensom, D. S. (1970). Some experimental and theoretical observations concerning mass flow in the vascular bundles of Heracleum. J. Exp. Bot. 21, 304-324. doi: 10.1093/jxb/21.2.304

van Bel, A. J. E., and Hafke, J. B. (2005). "Physiochemical determinants of phloem transport," in Vascular Transport in Plants, eds N. M. Holbrook and M. A. Zwieniecki (Burlington, CA: Academic Press), 19-44. doi: 10.1016/B978012088457-5/50004-6

Van Breusegem, F., and Dat, J. F. (2006). Reactive oxygen species in plant cell death. Plant Physiol. 141, 384-390. doi: 10.1104/pp.106.078295

Véry, A. A., and Sentenac, H. (2002). Cation channels in the Arabidopsis plasma membrane. Trends Plant Sci. 7, 168-175. doi: 10.1016/S1360-1385(02) 02262-8

Vignault, C., Vachaud, M., Cakir, B., Glissant, D., Dedaldechamp, F., Buttner, M., et al. (2005). VvHT1 encodes a monosaccharide transporter expressed in the conducting complex of the grape berry phloem. J. Exp. Bot. 56, 1409-1418. doi: $10.1093 /$ jxb/eri142

Vreugdenhil, D. (1985). Source-to-sink gradient of potassium in the phloem. Planta 163, 238-240. doi: 10.1007/BF00393513

Wada, H., Shackel, K. A., and Matthews, M. A. (2008). Fruit ripening in Vitis vinifera: apoplastic solute accumulation accounts for pre-veraison turgor loss in berries. Planta 227, 1351-1361. doi: 10.1007/s00425-008-0707-3

Walker, R., and Clingeleffer, P. (2009). Rootstock attributes and selection for Australian conditions. Aust. Vitic. 13, 69-76.

Walker, R. R., and Blackmore, D. H. (2012). Potassium concentration and pH interrelationships in grape juice and wine of Chardonnay and Shiraz from a range of rootstocks in different environments. Aust. J. Grape Wine Res. 18, 183-193. doi: 10.1111/j.1755-0238.2012.00189.x

Walker, R. R., Clingeleffer, P. R., Kerridge, G. H., Rühl, H., Nicholas, P., and Blackmore, D. H. (1998). Effects of the rootstock Ramsey (Vitis champini) on ion and organic acid composition of grapes and wine, and on wine spectral characteristics. Aust. J. Grape Wine Res. 4, 100-110. doi: 10.1111/j.1755-0238. 1998.tb00138.x

Wang, H. Y., Zhou, J. M., Du, C. W., and Chen, X. Q. (2010). Potassium fractions in soils as affected by monocalcium phosphate, ammonium sulfate and potassium chloride application. Pedosphere 20, 368-377. doi: 10.1016/S1002-0160(10) 60026-4

Wang, M., Zheng, Q., Shen, Q., and Guo, S. (2013). The critical role of potassium in plant stress response. Int. J. Mol. Sci. 14, 7370-7390. doi: 10.3390/ijms 14047370 
Wang, Y., and Wu, W. H. (2013). Potassium transport and signaling in higher plants. Annu. Rev. Plant Biol. 64, 451-476. doi: 10.1146/annurev-arplant050312-120153

Wheeler, S., Loveys, B., Ford, C., and Davies, C. (2009). The relationship between the expression of abscisic acid biosynthesis genes, accumulation of abscisic acid and the promotion of Vitis vinifera L. berry ripening by abscisic acid. Aust. J. Grape Wine Res. 15, 195-204. doi: 10.1111/j.1755-0238.2008.00045.x

Whitelaw-Weckert, M. A., Weckert, E. S., Rogiers, S. Y., Quirk, L., Clark, A. C., and Huang, C. X. (2011). Bacterial inflorescence rot of grapevine caused by Pseudomonas syringae pv. syringae. Plant Pathol. 60, 325-337. doi: 10.1111/j. 1365-3059.2010.02377.x

Williams, L. E., and Biscay, P. J. (1991). Partitioning of dry weight, nitrogen and potassium in Cabernet Sauvignon grapevines from anthesis until harvest. Am. J. Enol. Vitic. 42, 113-117.

Williams, L. E., and Matthews, M. A. (1990). "Grapevine," in Irrigation of Agricultural Crops, Agronomy Monograph No. 30, eds B. A. Stewart and D. R. Nielsen (Madison: ASA-CSSA-SSSA), 1019-1055.

Wolpert, J. A., Smart, D. R., and Anderson, M. (2005). Lower petiole potassium concentration at bloom in rootstocks with Vitis berlandieri genetic backgrounds. Am. J. Enol. Vitic. 56, 163-169.

Wong, D. C., Sweetman, C., Drew, D. P., and Ford, C. M. (2013). VTCdb: a gene co-expression database for the crop species Vitis vinifera (grapevine). BMC Genomics 14:882. doi: 10.1186/1471-2164-14-882

Zhang, L. Y., Peng, Y. B., Pelleschi-Travier, S., Fan, Y., Lu, Y. F., Lu, Y. M., et al. (2004). Evidence for apoplasmic phloem unloading in developing apple fruit. Plant Physiol. 135, 574-586. doi: 10.1104/pp.103.036632

Zhang, X. Y., Wang, X. L., Wang, X. F., Xia, G. H., Pan, Q. H., Fan, R. C., et al. (2006). A shift of phloem unloading from symplasmic to apoplasmic pathway is involved in developmental onset of ripening in grape berry. Plant Physiol. 142 220-232. doi: 10.1104/pp.106.081430

Zhang, Y. L., Meng, Q. Y., Zhu, H. L., Guo, Y., Gao, H. Y., Luo, Y. B., et al. (2008). Functional characterization of a LAHC sucrose transporter isolated from grape berries in yeast. Plant Growth Regul. 54, 71-79. doi: 10.1007/s10725-0079226-7

Zhao, L.-N., Shen, L.-K., Zhang, W.-Z., Zhang, W., Wang, Y., and Wu, W.H. (2013). $\mathrm{Ca}^{2+}$-dependent protein kinase 11 and 24 modulate the activity of the inward rectifying $\mathrm{K}^{+}$channels in Arabidopsis pollen tubes. Plant Cell 25, 649-661. doi: 10.1105/tpc.112.103184

Zhenming, N., Xuefeng, X., Wang, Y., Tianzhong, L., Jin, K., and Zhenhai, H. (2008). Effects of leaf-applied potassium, gibberellin and source-sink rate on potassium absorption and distribution in grape fruits. Sci. Hortic. 115, 164-167. doi: 10.1016/j.scienta.2007.08.012

Zörb, C., Senbayram, M., and Peiter, E. (2014). Potassium in agriculture- Status and perspectives. J. Plant Physiol. 171, 656-669. doi: 10.1016/j.jplph.2013.08.008

Conflict of Interest Statement: The authors declare that the research was conducted in the absence of any commercial or financial relationships that could be construed as a potential conflict of interest.

Copyright (C) 2017 Rogiers, Coetzee, Walker, Deloire and Tyerman. This is an openaccess article distributed under the terms of the Creative Commons Attribution License (CC BY). The use, distribution or reproduction in other forums is permitted, provided the original author(s) or licensor are credited and that the original publication in this journal is cited, in accordance with accepted academic practice. No use, distribution or reproduction is permitted which does not comply with these terms. 